\title{
Lingüística: La ciència del llenguatge
}

\section{RESUM}

En aquest article es presenten els diversos aspectes d'una aproximació científica al llenguatge. Una de les principals conseqüències d'adoptar els principis metodològics propis de les ciències és que la lingüística no pot ser una ciència de les llengües, perquè, des d'aquesta perspectiva és impossible donar una definició objectiva de llengua. Per això, l'objecte d'estudi de la lingüística no pot ser altre que la facultat del llenguatge, entesa com a la capacitat pròpia de tot individu de l'espècie humana que ens permet desenvolupar i posar en ús coneixements lingüístics. Un cop establerts aquests supòsits bàsics, el text esbossa la mena de problemes als quals s'enfronta la recerca en aquest àmbit i reflexiona sobre algunes de les principals aproximacions metedològiques que hom pot adoptar per tal de buscar respostes als esmentats problemes.

PARAUlES CLAU: Llengua vs. Llenguatge, Faculat del llenguatge, Desenvolupament del llenguatge, Variació lingüística, Processament del llenguatge, Fonologia, Sintaxi, Semàntica. 


\section{ABSTRACT}

In this paper we sketch a number of issues pertaining to a scientific approach to the study of language. One of the main consequences of adopting the methodological principles typical of the sciences is that linguistics cannot be seen as a science of languages, because from this perspective it is impossible to provide an objective definition of language. It is precisely for this reason that the object of study of linguistics can only be the faculty of language, understood as that capacity, with which all members of the human species are endowed, that makes it possible to develop and put to use linguistic knowledge. Once these basic assumptions have been established, the paper outlines some of the main problems faced by this research program and reflects upon some of the methodological strategies one may adopt when trying to find answers to these questions.

KEY WORDS: syntax, metalinguistic awareness, multiple intelligences, didactic sequence.

\section{ÍNDEX}

1. Introducció: però, de fet, què és el llenguatge?

2. Una agenda per a la lingüística

3. Desenvolupament de la proposta

4. Conclusions

5. Bibliografia

\section{Introducció: però, de fet, què és el llenguatge?}

Fer de lingüista és, a voltes, enutjós. I ho és perquè poques vegades la gent del carrer comprèn—o sap-què fan els lingüistes. Considereu l'intercanvi següent:

-I tu, com et guanyes la vida?

-Doncs, sóc lingüista.

-Lingüista! Vaja! Llavors deus parlar moltes llengües, oi?

-Alguna, sí, però...

No, els lingüistes no sempre parlen moltes llengües. Alguns sí, és clar-finalment, als lingüistes els agraden les llengües-, però per ser lingüista no cal ser un políglota. 
$\mathrm{O}$ considereu ara aquest diàleg:

-I tu, com et guanyes la vida?

-Doncs, sóc lingüista.

-Lingüista! Vaja! Llavors segur que pots ajudar-me amb això: quina és la forma correcta de dir

<inseriu aquí la vostra paraula, frase $o$ expressió favorita>. -Mira, no n'estic del tot segur, per què no ho consultes al diccionari? -Però què dius? Tu ets lingüista, no?

Als lingüistes (en tant que lingüistes, és clar) els importen ben poc les normes. Lliçó primera: la lingüística no és una disciplina normativa i, per tant, no li incumbeixen les qüestions de correcció: ni de correcció lingüística, ni de correcció política ni del que sigui. Als lingüistes els interessa el llenguatge i, per extensió, també els interessen les llengües (una subtil distinció sobre la qual cadrà que tornem més endavant); els lingüistes volen saber com funciona el llenguatge i, per tant, el seu objectiu és (principalment) explicatiu, com ho és el de qualsevol altre científic. Els lingüistes estudien el llenguatge, sí, la lingüística va d'això, però què és realment el llenguatge?

Aquesta és una pregunta dolorosa.

I és dolorosa perquè és la demostració fefaent que, després de gairebé cent anys, la lingüística ha estat incapaç de fer arribar el missatge. Tothom sap (més o menys) què fan els físics, els biòlegs, els químics, els geòlegs, els psicòlegs (la majoria), els arqueòlegs, els matemàtics, els historiadors, fins i tot els economistes; bé, pel que fa als darrers ni jo mateix n'estic del tot segur, però veieu per on vaig, oi? Poques persones semblen saber de què va realment la lingüística. És per això que intentaré explicar-vos-ho. I el meu primer pas en aquesta direcció serà dir-vos allò que el llenguatge no és. Hi ha, òbviament, moltes coses que el llenguatge no és i, per exemple, el llenguatge no és un objecte abstracte. Amb el terme 'objecte abstracte' vull referir-me a aquelles entitats que no estan subjectes a les lleis naturals, com ara la força de la gravetat o, simplement, les lleis de l'espai i del temps-els objectes 
abstractes no tenen història i no sembla tampoc que ocupin espai. Els típics objectes d'aquesta mena són objectes matemàtics com els que teniu a la Figura 1.

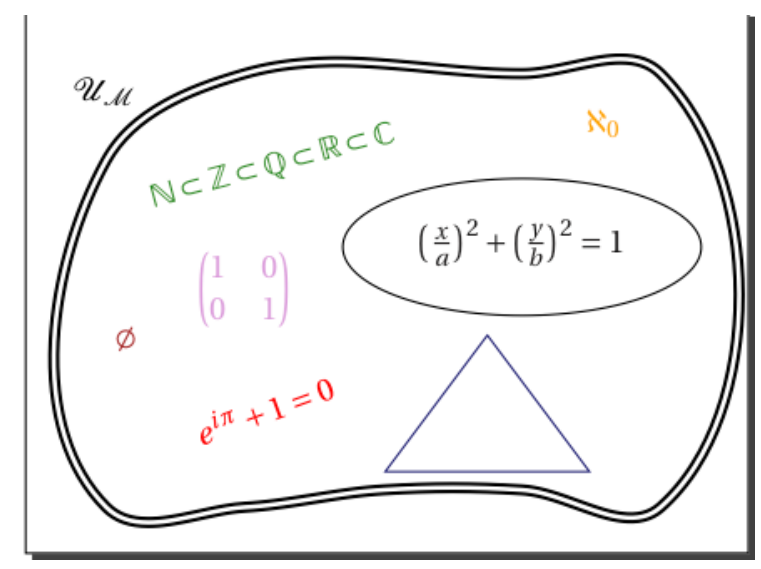

Figura 1: L'univers dels objectes matemàtics-la fòrmula d'Euler en vermell; els nombres naturals, enters, racionals, reals i complexos, representats com a subconjunts de conjunts d'ordre superior, en verd; un triangle equilàter en blau; l'el-lipse amb la seva equació (circumscrita) en negre; la matriu identitat de $2 \times 2$, I2, en lila; el conjunt buit en marró; i el cardinal del conjunts dels nombres naturals, àlef zero, en taronja.

No ens cal entendre què és $U_{\mathcal{M}}$ exactament-això és feina per als filòsofs de les matemàtiques-per adonar-nos que l'afirmació que el llenguatge no és una entitat que resideix en un univers abstracte semblant (o idèntic) a l'univers $\mathcal{U}_{\mathcal{M}}$ dels objectes matemàtics no és una afirmació innocent; no ho és, no, d'innocent, i està plena de connotacions interessants. I una connotació particularment rellevant és que els procediments de descoberta que apliquen els lingüistes en la seva recerca són totalment diferents dels que usen els matemàtics quan discorren sobre els objectes matemàtics. De fet, la recerca en lingüística és empírica en el mateix sentit que la recerca en física, biologia, química o geologia és empírica. En altres paraules, el llenguatge és un objecte natural i els mètodes, procediments, supòsits i eines de la lingüística són, a la pràctica, no molt diferents dels de qualsevol ciència natural. Evidentment, això no exclou les matemàtiques de la caixa d'eines del lingüista: la 
lingüística matemàtica és matemàtica aplicada, no una branca de les matemàtiques que estudia un tipus especial d'objecte matemàtic.

M'atreviria a dir que, avui en dia, tots (gairebé tots) els lingüistes estan d'acord amb això. ${ }^{1}$ Tota una altra cosa és, evidentment, si tothom està d'acord sobre quin és el lloc que ocupa el llenguatge dins l'economia de la natura, perquè, llavors, la resposta no pot ser altra que un no rotund.

Crec que és el moment per a un altre dels nostres diàlegs exemplars:

-El llenguatge és el sistema de comunicació propi dels humans i, de la mateixa manera que els humans tenen el llenguatge, també les abelles, les mones, els ocells, tots els animals de fet-potser fins i tot les plantes-tenen el seu llenguatge. La lingüística no és altra cosa que una part de la teoria general de la comunicació.

-Bé, la veritat, de fet, és que no. La comunicació, si de cas, té alguna cosa a veure amb l'acció, però amb el llenguatge... I, a més a més, tampoc és tan evident que els altres animals tinguin llenguatge, saps?

-Au vinga! Però què dius! Tothom sap que els animals es comuniquen i que ho fan utlitzant algun llenguatge. A més a més, el meu gos m’entén quan li parlo.

\section{Això m’avorreix extremament.}

I l'única cosa que puc fer és respondre amb una citació:

There is no study of 'language' ranging from ants, to chimps, to human language, to formal arithmetic, any more than there is a study of 'locomotion' ranging from amoeba to eagle to sciencefiction space ship; or 'communication', ranging from cellular interaction to Shakeaspeare's sonnets to 'intelligent' extraterrestrials. ${ }^{2}$

(Noam Chomsky. 1993. Language \& Thought, p. 29)

\footnotetext{
${ }^{1}$ La veritat és que fins i tot en això hi ha un cert desacord-hi ha lingüistes que sí creuen que el llenguatge és un objecte abstracte. Per fer-vos una bona d'idea de per on van aquests debats sobre l'estatus ontològic del llenguatge, us pot interessar de llegir l'article de Barbara C. Scholz, Francis Jeffrey Pelletier i Geoffrey K. Pullum The philosophy of linguistics a la Stanford Encyclopedia of Philosophy, on coneixereu en Jerrold Katz, un lingüista que pensava que les llengües naturals son "timeless, locationless, and necessarily existent" ("atemporals, sense ubicació i necessàriament existents"); és a dir, exactament el contrari que jo acabo de suggerir en el text.

$2<<$ No hi ha estudi del 'llenguatge' que vagi de les formigues, als ximpanzès, al llenguatge humà o a l'aritmètica formal, de la mateixa manera que no hi ha una ciència de la 'locomoció' que vagi de les amebes a les àligues i les naus espacials de la ciència-ficció; o de la 'comunicació' que vagi de la interacció ce"lular als sonets de Shakespeare i als extraterrestres 'intel-ligents'.>>
} 
La veritat és que no tinc intenció de perdre gaire temps discutint sobre això. De fet, no ho faré i em limitaré a assumir que Chomsky té tota la raó a dir el que diu. ${ }^{3}$

El que faré és una altra cosa. Us proposaré una agenda de recerca completa per a la lingüística. Però això ho faré en la secció següent.

\section{Una agenda per a la lingüística}

Seguint la línea encetada en la secció anterior, assumiré que estem més o menys d'acord amb la idea que l'element central del projecte de recerca de la lingüística és la naturalització del llenguatge. Amb 'naturalització' no vull dir altra cosa que cal considerar el llenguatge com un objecte natural, una entitat que és part del món en què vivim, com ho són els àtoms, l'ADN, l' $\mathrm{H}_{2} \mathrm{O}$ o les plaques tectòniques. Una conseqüència immediata d'aquest supòsit és, com també he assenyalat a la Secció 1 , metodològica: la lingüística és una ciència natural i, com a tal, ha de desenvoluparse d'acord amb els principis i els mètodes propis de les ciències naturals. Una afirmació aparentment tan innocent com aquesta imposa, de fet, un important nombre de restriccions sobre les menes de supòsits que hom pot adoptar. En aquest sentit, hi ha una restricció particularment forta en relació amb el fet que els tipus d'objectes que estudien les ciències naturals són allò que habitualment es coneix amb el nom de classes naturals o, en altres paraules, entitats que és possible individuar a partir d'una sèrie de criteris objectius. Això és precisament el que passa amb els àtoms, l'ADN, l' $\mathrm{H}_{2} \mathrm{O}$ i les plaques tectòniques: hi ha maneres de verificar (aquest és un terme una mica passat de moda, però que tanmateix usaré per la seva claredat) que les dites entitats naturals existeixen independentment dels (pre)judicis de l'observador-si algun dia trobem aigua a Mart, immediatament la reconeixerem com una mostra d' $\mathrm{H}_{2} \mathrm{O}$; similarment amb els altres casos. Aquesta restricció és prou forta i situa la lingüística en la difícil situació d'haver d'especificar una col-lecció de criteris objectius per tal d'individuar el seu objecte d'estudi, és a dir el llenguatge. A

3 Si insistiu, aquí teniu una referència que podeu descarregar-vos: Sergio Balari \& Guillermo Lorenzo. 2010. Communication: where evolutionary linguistics went wrong. Biological Theory 5(3):228-239. 
més a més, i com també acostuma a ser pràctica habitual en les ciències naturals, una estratègia raonable que se sol seguir en aquests casos és la d'identificar aquells problemes que es presenten com a mínimament tractables per tal de garantir un cert progrés-obsessionar-se a respondre preguntes impenetrables és la millor manera d'empantanar-se i, eventualment, caure en la paràlisi absoluta. És per aquest motiu que, per molt intuïtiu i raonable que sembli a primera vista l'enfocament comunicatiu, aquest planteja tota una colla de dificultats que poden, si és que no ho han fet ja, dur el camp a la paràlisi. Fins i tot es podria donar el cas que fos un enfocament incoherent, però aquí em limitaré a assenyalar que una teoria general de la comunicació és, en tot cas, part pròpia d'una teoria general de l'acció o de per què i com un organisme fa les coses que fa. Dit d'una altra manera, una teoría general de la comunicació és part pròpia d'una teoria general de la conducta i explicar el comportament-els perquès i els coms del comportament-és realment molt difícil: pregunteu-li-ho als psicòlegs. ${ }^{4}$ L'estratègia, doncs, consistiria a fixar-se uns objectius més modestos, seguint els passos suggerits pel propi Chomsky en les referències de la nota 4. Potser en un futur serem capaços de dir alguna cosa coherent o mínimament raonable sobre la comunicació, però, a dia d'avui, el més recomanable sembla ser adoptar un enfocament més conservador.

Perquè us feu una idea de quin pot ser aquest enfocament més conservador, en la subsecció següent us proposaré de fer un experiment mental molt simple en el qual l'única condició que imposaré serà la de no anar més enllà d'allò que dicta el sentit comú i d'acceptar les conclusions del nostre raonament tal com ragin.

Som-hi, doncs!

\subsection{Preliminars ontològics}

\footnotetext{
${ }^{4}$ Noam Chomsky sempre ha defensat la idea que les ments humanes tenen límits sobre la mena de coses que aquestes són capaces de comprendre o, en les seves pròpies paraules, que hi ha problemes i que hi ha misteris; i els darrers transcendeixen els límits de les nostres capacitats cognitives. L'explicació de l'acció, de la conducta, s'aproximaria a allò que Chomsky entén per misteri. Ell mateix ho explica prou bé en aquest breu vídeo; si alternativament preferiu consultar la font original, la dicotomia entre problemes i misteris, Chomsky la va exposar per primera vegada a la Part II del seu llibre publicat el 1975 Reflections on Language, titulada, com no podria ser d'una altra manera, "Problems and mysteries in the study of human language".
} 
Imagineu que sou a l'aula 108 de la Facultat de Filosofia i Lletres de la UAB i que algú-jo mateix per exemple-està impartint-vos una classe sobre els problemes i els misteris en l'estudi del llenguatge humà. Això no hauria de ser gaire difícil. Ara, i en la mesura que el docent està fent servir una llengua comuna-posem que és el català-i vosaltres l'esteu escoltant, llavors crec que és lícit afirmar que enteneu allò que us diu. Certament, poden presentar-se algunes dificultats amb el significat de certs conceptes nous per al quals calgui, més endavant, fer alguns aclariments, però no és aquí on vull anar. On vull arribar és al fet que sou capaços de copsar allò que diu el professor. I no només això, sinó que ho feu en temps real i, això, és molt ràpid! En aquest punt, la següent pregunta no pot ser més que aquesta: Com ho feu?5 $\mathrm{A}$ mida que avanci, anireu descobrint que sempre és més fàcil donar resposta a preguntes sobre el com que a preguntes sobre el perquè de les coses. ${ }^{6}$ Per exemple, la pregunta 'per què ho feu?' és molt difícil de respondre, pot tenir moltes respostes possibles o, el que és més probable, potser ni tan sols té sentit; la pregunta 'com ho feu?', en canvi, es pot respondre, encara que sigui parcialment, amb quelcom com ara l'esquema que teniu a la figura 2.

\footnotetext{
5 Podria haver començat preguntant 'On ho feu?', tot i que sospito que, a menys que sigueu la reencarnació d'Aristòtil, que pensava que el locus de la raó era el cor, tothom té prou clar que l'actor principal en aquesta història és el cervell.

6 Això comporta assumir que l'explicació en les ciències naturals és eminentment mecanicista o, dit d'una altra manera, que l'objectiu de la ciència és descobrir i comprendre com funciona el món, quins són els mecanismes subjacents als diferents fenòmens que observem en la natura. Des d'una perspectiva històrica, això no és més que una versió actualitzada del programa racionalista de Descartes i Leibniz, que sovint van utilitzar la màquina com a metàfora de la Natura: la natura com mecanisme de rellotgeria. La naturalització del llenguatge i, per extensió, de la ment a què estic apel-lant aquí és per tant la continuació lògica d'aquest programa, incorporant en aquest cas la ment (i el llenguatge) com a part integrant de la Natura, a diferència del que defensaven Descartes i Leibniz, que consideraven que la ment estava feta d'una substància totalment diferent i, per tant, no podia ser explicada mecanísticament. El principis bàsics de la filosofia mecanicista els va desenvolupar Descartes en el seu Traité du monde et de la lumière, conegut genèricament com El món.
} 


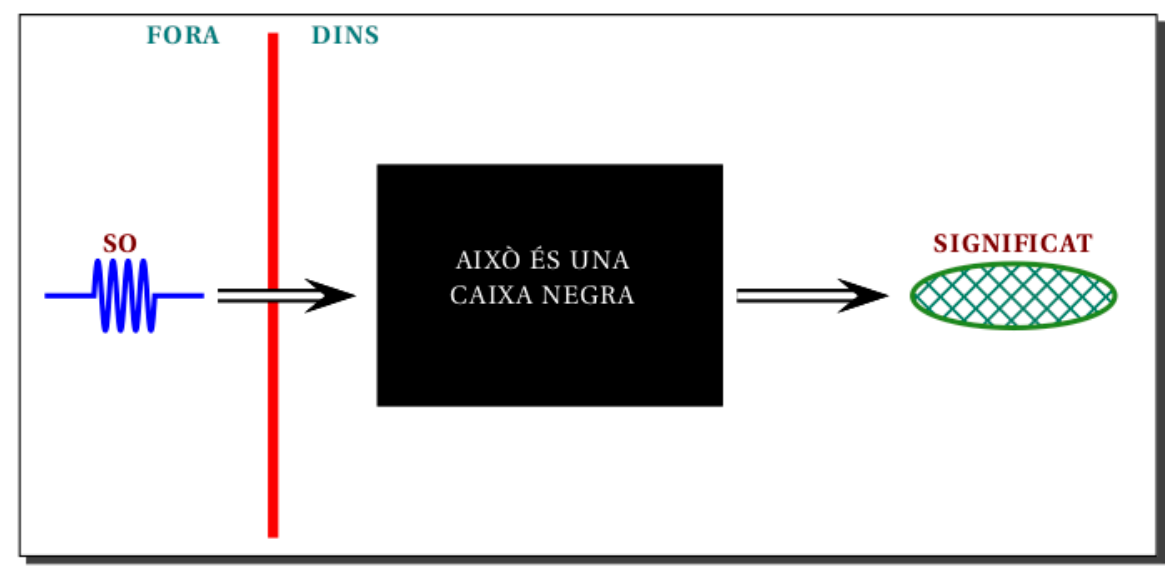

Figura 2: Una primera aproximació a respondre com arribem a entendre allò que ha dit el nostre interlocutor.

Vull remarcar que allò que la figura il-lustra es pot inferir simplement utilitzant el nostre sentit comú. Permeteu-me que ho faci explícit. Primerament, tenim que algú ha dit alguna cosa i nosaltres ho copsem com un estímul acústic, com un so. Els sons són entitats físiques que, com ens ensenya la fonètica acústica, poden ser analitzades com a ones-això és el que la línia blava en ziga-zaga vol representar en la figura. Les nostres orelles capturen aquest so, que serà processat per la nostra oïda, la qual, al seu torn, trametrà aquesta informació al nostre cervell. El detalls de com s'arriba fins aquí els he omès i m'he limitat a abreujar-los mitjançant la fletxa que creua la barrera vermella. Aquesta barrera representa la separació entre allò que és extern (el món) i allò que és intern (el cervell).7 Més endavant afegiré nous detalls, però, de moment, vull que concentreu la vostra atenció en el fet que el nostre cervell rep informació sobre el so i que, d'alguna manera, és capaç d'aparellar aquest so amb un significat. A aquestes alçades de la història no ens cal saber què són exactament els significats (no és cosa fàcil, us ho ben asseguro) i a la figura els represento com a el-lipses tramades en verd. El que importa ara i aquí és que el nostre cervell és capaç de trobar el significat que es correspon amb el so copsat pel nostre sentit de l'oïda. Tenim, per

\footnotetext{
${ }^{7}$ En el supòsit que aquesta dicotomia extern vs. intern tingui realment sentit, la qual cosa no és del tot òbviafinalment, el cervell també és part del món, oi? De tota manera, no ens complicarem la vida i assumiré que, al menys des del punt de vista metodològic, aquesta dicotomia té sentit.
} 
tant, una informació d'entrada (o, si ho preferiu, un input)-el so-i una informació de sortida (o output) -el significat. Tenim, en altres paraules, el que podem descriure com un procés d'input-output o, també, una computació. És a dir, el nostre cervell és capaç d'executar una operació computacional que, donat un so com a informació d'entrada, és capaç de retornar un significat com a informació de sortida. No sabem exactament quina mena d'operacions computacionals executa el nostre cervell per obtenir aquests resultats, però és un fet inqüestionable que és capaç de fer-ho o, al menys, això és el que el sentit comú sembla dictar. Assumiré que aquesta intuïció és una bona intuïció i aniré desenvolupant-ne les conseqüències que se'n deriven. Com que, de moment, poc o gens sabem del procés en qüestió, l'he representat com una caixa negra. Això és el que la caixa negra de la figura representa: la nostra ignorància.

Però això no ens ha de desanimar, perquè ara sabem què no sabem, ja que hem identificat un nou problema, podem formular una altra pregunta sobre un com: com aparellem sons amb significats? El que volem és obrir la caixa negra de la figura [2] i mirar de donar una resposta més precisa a la pregunta 'com ho fem?'. Bé, doncs ara anomeneu 'Llenguatge' la caixa negra i ja tindreu una idea, per vaga que sigui, de quin és l'objecte de la lingüística: la lingüística és la ciència que s'ocupa d'esbrinar què hi ha dins aquesta caixa negra que els lingüistes anomenen 'Llenguatge'. Evidentment, 'Llenguatge' tal i com l'acabem de definir és un terme tècnic el significat del qual, no podria ser d'una altra manera, no té perquè correspondre's amb altres sentits que podem donar-li a la paraula 'llenguatge'. Però això és el pa de cada dia en ciència: és molt important saber distingir el significat que una determinada disciplina científica dóna a un determinat terme tècnic del significat (o significats) que la mateixa paraula pugui tenir en la parla diària-'or' no significa necessàriament el mateix per a un químic, per a un orfebre o per a una persona a qui li agraden les joies fetes d'or. ${ }^{8}$

\footnotetext{
8 Per a un químic, el significat d'or' està prou clar, significa 'element amb nombre atòmic 79'. I punt. Ara consulteu la paraula 'or' en un diccionari (el DIEC, per exemple) i veureu que, a més a més de la definició científica, hi trobareu altres significats.
} 
Ha arribat el moment de recollir els fruits de la nostra reflexió fins el moment. Tot el que acabo de dir té algunes conseqüències prou profundes i convé fer-les explícites. Primerament, he definit 'Llenguatge' com allò (el que sigui) que permet als humans aparellar estímuls acústics amb significats. Això captura una intuïció molt antiga que es remunta fins als temps d'Aristòtil, segons la qual el llenguatge seria precisament això, so més significat. Aquesta definició, no gaire precisa tot sigui dit, també la trobareu en els escrits més recents de Chomsky, així que, en aquest sentit, podem afirmar que la perspectiva contemporània manté una certa continuïtat històrica amb perspectives més antigues. Segonament, noteu que la definició no implica que el Llenguatge sigui una 'cosa'; pot ser que sigui alguna cosa però no cal que sigui necessàriament així. El que la definició sí comporta és que el Llenguatge és una capacitat humana, la capacitat d'aparellar sons amb significats, o, millor, comporta que el Llenguatge és una facultat. Altre cop, aquesta idea no és pas nova, té com a mínim alguns segles i, de fet, la trobem formulada de forma explícita per Descartes, qui creia que les facultats eren el potencial o la predisposició a desenvolupar i posar en ús certes destreses o habilitats. ${ }^{9}$ És per aquest motiu que els lingüistes, enlloc d'usar el terme 'Llenguatge', per evitar confusions, prefereixen

\footnotetext{
${ }^{9}$ L'evidència textual del que acabo de dir és aquesta:

$<<$ En l'article dotze el desacord de l'autor amb mi em sembla ser merament verbal. Quan ell diu que la ment no té necessitat d'idees, o nocions, o axiomes que siguin innats, al mateix temps que admet que la ment té el poder de pensar (presumiblement natural o innat), està clarament dient la mateixa cosa que jo, tot i negar-la verbalment. Mai no he escrit ni adoptat la posició que la ment necessita idees innates que siguin quelcom de diferent que la seva pròpia facultat de pensar. Sí he observat, tanmateix, que hi havia certs pensaments en mi que ni em venien d'objectes externs ni eren determinats per la meva voluntat, sinó que procedien només del meu poder de pensar; així, vaig aplicar el terme 'innat' a les idees o nocions que són les formes d'aquests pensaments a fi de distingir-les d'aquelles que vaig denominar 'adventícies' o 'fabricades'. Aquest és el mateix sentit en què diem que la generositat és 'innata' en certes famílies, o que certes malalties com la gota o les pedres al ronyó són innates en altres: no es pot dir que els infants d'aquestes famílies patissin aquestes malaties ja en el ventre de la mare, sinó que han nascut amb una certa 'facultat' o tendència a contreure-les.
}

[...] Conseqüentment, aquestes idees i aquesta facultat són innates en nosaltres, és a dir, sempre existeixen en nosaltres potencialment, ja que existir en una facultat no és existir realment, sinó només potencialment, atès que el terme 'facultat' no denota altra cosa que una potencialitat. >>

Les paraules són de Descartes i provenen d'un opuscle titulat Comentaris a un cert pamflet (Notae in Programma quoddam, Amsterdam, 1648), redactat com a resposta a un pamflet publicat anònimament pel professor de medicina de la Universitat d'Utrecht Henry de Roy (Henricus Regius) el 1647. Com veieu, l’innatisme cartesià és molt més sofisticat del que sovint se'ns vol fer creure. Per cert, la traducció és meva a partir de la versió anglesa de John Cottingham i publicada a John Cottingham, Robert Stoothoff \& Dugald Murdoch, eds. 1985. The Philosophical Writings of Descartes. Volume I. Cambridge: Cambridge University Press, pp. 293-312. 
parlar de 'Facultat del Llenguatge' o, simplement, FL per abreujar. Pels mateixos motius, jo adoptaré també aquesta convenció i, així, evitaré al màxim que us vinguin al cap els molts altres significats que té associats la paraula 'llenguatge'. Dit això, ja podem afegir que la FL és una facultat del nostre cervell; per tant, estudiar la FL té alguna cosa a veure amb la psicologia humana $i$, eventualment, amb la neurociència. En la mesura que la neurociència és una branca de la biologia, per transitivitat, la lingüística és també una branca de la biologia (humana).

I, això, no és trivial.

I no és trivial perquè llavors, crucialment, la lingüística entesa com a ciència de la FL tal i com l'acabo de definir no és una ciència social. Això no significa que no hi ha un aspecte social del llenguatge, sinó que quan parem atenció a aquest aspecte social del llenguatge, quan fem sociolingüística, estem adoptant una perspeciva totalment diferent de la que jo he descrit fins ara. La lògica darrere el que acabo de dir hauria de ser prou clara si tornem per un moment a la figura [2]. Recordeu que la situació que us convidava a imaginar era aquella en què una persona parla davant d'una audiència. En aquesta situació, l'estímul acústic és, clarament, un i només un: les paraules pronunciades pel conferenciant. Tanmateix, totes i cada una de les persones que l'escolten està executant l'acte individual de processar aquest estímul per tal d'aparellar-lo amb un significat. Per tant, en aquesta situació, hi ha tantes FL com persones conformen l'audiència. La FL és una entitat individual, personal i intransferible: hi ha, de fet, tantes FL com membres té (ha tingut/tindrà) l'espècie humana. És per aquest motiu que, quan ens preguntem sobre la naturalesa de la FL, sobre com està organitzada, sobre com funciona, etc., ho fem abstraient-la del context social en què estan immerses les persones que tenen una FL. L'enfocament sociolingüístic, en canvi, assumeix l'existència de la FL i s'ocupa d'investigar com les persones la posen en ús en situacions específiques. En molts sentits, doncs, la recerca en els aspectes socials del llenguatge té molt a veure amb la teoria de l'acció a què feia referència més amunt: és l'estudi de la conducta lingüística, incorporant una teoria de la FL més moltes altres coses, com ara una teoria sobre les causes de la conducta (la conducta lingüística inclosa). Intentar de descobrir què és la FL i com 
funciona és un objectiu molt més modest i és en aquest objectiu que se centra aquest text que esteu llegint.10

Arribats a aquest punt, em sembla que cal dir alguna cosa sobre les llengües. En poques paraules, les llengües, posats a atribuir-los algun estatus, serien les manifestacions de la conducta lingüística; però fins i tot aquesta definició no és satisfactòria. Per un motiu: l'estatus ontològic de les llengües no és prou clar, perquè no és obvi que se les pugui considerar com a classes naturals en qualsevol de les interpretacions del terme. El problema amb paraules com ara 'anglès', 'japonès' o 'georgià' és que, malgrat que el seu significat col-loquial sembla ser més o menys clar, no és evident que facin realment referència a entitats naturals per a les quals sigui possible donar una definició que no sigui problemàtica. Preneu, per exemple, l'anglès. Què és la llengua anglesa? Bé, diguem de moment que és la llengua majoritària que es parla als Estats Units, al Regne Unit, al Canadà, a Austràlia i a Nova Zelanda, així com una de les llengües parlades a Sud-àfrica, a Irlanda, a l'Índia i a moltes de les antigues colònies britàniques d'Àfrica (com Nigèria i Kenya) i Àsia (com Hong Kong); podeu consultar l'article corresponent de la Viquipèdia per tenir una idea més clara de la seva distribució geogràfica. Estic segur que sabeu, però, que l'anglès que es parla en tots aquests llocs no és el mateix anglès: tenim l'anglès britànic, l'anglès americà, l'anglès canadenc, etc. Però fins i tot en el cas de l'anglès americà, no es pot afirmar que sigui una parla uniforme: hi ha variació, com podeu comprovar fent una visita a l'Atlas of North American English, on trobareu una llista dels seus dialectes. Tot i així, podríem seguir refinant la nostra anàlisi i identificar petites diferències entre l'anglès que es parla, per exemple, a San Francisco i Salt Lake City (dues ciutats dins de l'àrea dialectal occidental) i, així, successivament fins a arribar a identificar diferències individuals en la forma de parlar-lo: és simplement

\footnotetext{
10 Estic intentant ser tant neutral com puc, però si teniu la sospita que en el punt que acabo de tractar en el text hi ha nombrosos desacords, doncs l'heu encertada de ple. Així, per una banda, Ferdinand de Saussure en el seu Cours de linguistique générale, publicat pòstumament el 1916, va dir que la lingüística és una branca de la psicologia social i que l'entitat que ell anomenava 'Llenguatge' (bé, ell ho va dir en francès, 'Langue') seria allò que comparteixen tots els membres d'una determinada comunitat de parlants. Per altra banda, uns quaranta anys després, Noam Chomsky va desenvolupar la definició de llenguatge que es correspondria amb la definició de FL que jo he donat en el text. Dit això, i depenent de com us sentiu avui de dogmàtics, podeu pensar que els dos enfocaments són totalment incompatibles o, alternativament, que hom pot fer certes concessions per tal de fer-los compatibles-més qualsevol opció intermèdia que se us acudi, és clar. Però, això, és cosa vostra, no meva.
} 
una qüestió del grau de precisió que vulguem assolir, fent zooms allunyant-nos o apropant-nos, des de les idiosincràsies individuals fins als trets comuns en la manera de parlar de comunitats cada vegada més nombroses. Vist des d'aquesta perspectiva, no és clar que hi hagi una cosa que mereixi l'etiqueta de la llengua anglesa més enllà de la definició, prou difusa (i circular), segons la qual l'anglès és la llengua que parlen aquelles persones que parlen anglès. El cert és que aquesta és, de fet, una bona aproximació a la millor de les definicions que podem construir i que seria més o menys aquesta: l'anglès és el conjunt de maneres de parlar característic d'aquells parlants que es consideren a si mateixos com a parlants de l'anglès. Si us hi fixeu, observareu que aquesta definició introdueix un element de subjectivitat ineliminable, és a dir, el sentiment compartit per un grup de persones de ser parlants de la mateixa llengua; però, això, com ja he dit més amunt, no està permès en la definició d'una classe natural. El problema amb els sentiments és que poden canviar i, per exemple, una comunitat de persones que s'identifica com a parlant d'una determinada llengua pot, en un cert moment, canviar d'idea (de sentiment) i decidir que és parlant d'una altra llengua. O podem trobar-nos amb dues comunitats de parlants que diuen parlar llengües diferents però la seva manera de parlar és, en molts sentits, molt semblant $i$, a la vegada, molt diferent de la manera de parlar d'altres comunitats, potser geogràficament distants, que suposadament parlen la mateixa llengua. Això no són fantasies; aquestes coses passen. Constantment. Només a Europa en tenim un bon grapat d'exemples d'un cas i de l'altre.

Heu sentit parlar mai del serbocroat? Probablement no, però potser sí que heu sentit parlar del croat, del serbi, potser fins i tot del bosnià i del montenegrí, parlats, respectivament, a Croàcia, Sèrbia, Bòsnia i Hercegovina i Montenegro. Quan jo era jove, hi havia només el serbocroat, una de les llengües que es parlava a Iugoslàvia; però hi va haver una guerra...

Per trobar un exemple de la segona situació, només cal que investigueu una mica sobre els dialectes coneguts amb els noms de baix saxó o baix alemany (gairebé intercanviables). Si ho feu, descobrireu que històricament són molt més a prop del neerlandès, tant del flamenc com de l'holandès, que no pas de l'alt alemany (que és allò que genèricament tots anomenem alemany). Tanmateix, les actituds dels seus 
parlants són molt canviants i depenen, sobretot, de si són ciutadans de la República Federal d'Alemanya, dels Països Baixos o de Bèlgica.

Per tant, termes com ara 'alemany', 'anglès' o 'francès' són meres etiquetes que els lingüistes usen per classificar de manera més o menys aproximada les dades amb què treballen, però aquestes etiquetes poden ser reemplaçades fàcilment per d'altres, com ara 'indoeuropeu' o 'germànic' o 'romànic' o 'alemany suís' o 'scots' o 'quebequès', en funció de quin sigui el focus d'interès. Quan hom vol destacar trets comuns pot ser apropiat usar termes més generals, mentre que quan volem centrar la nostra atenció en certs detalls, pot ser més convenient fixar-se en varietats o subvarietats lingüístiques.

A aquestes alçades, és probable que sospiteu que no hi ha una definició científica d'anglès (o de català o de castellà) que sigui fiable, ni, de fet, de la tradicional dicotomia entre llengua i dialecte, i que totes aquestes qüestions són més aviat assumptes que incumbeixen més la psicologia social que no pas la lingüística. A més a més, aquestes qüestions sovint (d'això segur que en sou prou conscients) es barregen amb d'altres com ara la religió, la nacionalitat, l'etnicitat i altres sentiments identitaris. Tot plegat comporta que, sens dubte, hi ha una sociologia del llenguatge (o de les llengües), però també és (o hauria de ser) obvi que els seus interessos ultrapassen de llarg els límits del que seria (o hauria de ser) l'estricte estudi científic de la FL, que és el que m'interessa tractar aquí. En el que queda d'article, seguiré usant etiquetes com 'català', 'suahili' o 'mandarí', però, evidentment, cal que les interpreteu d'acord amb les prevencions i matisos que tot just acabo d'introduir.

\subsection{L' agenda}

Un cop hem fet explícit el nostre compromís ontològic-volem saber més coses sobre la FL-, ara ja puc començar a delinear una agenda de recerca per a la lingüística. En fer-ho, intentaré identificar alguns problemes centrals així com conjunts de subproblemes i preguntes de difícil resposta que plantegen aquests grans problemes centrals. L'ordre en què els presento no en representa la importància o la centralitat, sinó, més aviat, reflecteix el que em sembla que us pot resultar més familiar, que és per on començaré. 


\section{Com s'estructura la FL?}

Això és, en certa manera, la lingüística de tota la vida; o, potser, allò que a l'escola i a l'institut en dieu 'llengua'. Però només aproximadament. Quan hom estudia 'llengua' a l'escola o a l'institut, aquesta paraula acostuma anar acompanyada de l'adjectiu 'catalana' o 'castellana' i, sí, estudia coses que porten associades etiquetes tals com 'fonètica', 'fonologia', 'morfologia', 'sintaxi' i 'semàntica'. En aquest sentit, aquest ítem de l'agenda pot semblar que va exactament d'això en la mesura que, sí, tota recerca dins d'aquest àmbit pot rebre també etiquetes com les de 'fonètica', 'fonologia', etc. Però la semblança és només superficial. No oblideu què és la FL: un caixa negra. I qualsevol intent d'obrir-la passa per la voluntat d'intentar entendre com està organitzada. En fer això, de fet, intentem determinar en quina mesura aquestes etiquetes tenen realment un significat, ja que el nostre és un objectiu científic i el que realment volem saber és si en les capacitats lingüístiques humanes realment hi ha quelcom que mereixi, per exemple, el nom de 'sintaxi' o de 'morfologia'. Volem saber, a més a més, com s'interrelacionen, si és que ho fan, i quin paper juguen en el procés d'aparellar sons amb significats. I, una altra cosa per acabar, les etiquetes 'catalana' o 'castellana' deixen de tenir sentit: estem investigant la FL i tots els humans, per hipòtesi, la tenen organitzada més o menys igual. Evidentment, no tots els humans parlen la mateixa llengua i, per això, alguna diferència hi ha d'haver entre les FL d'uns i altres. Per això són tant importants els següents punts de l'agenda.

\section{Com es desenvolupa la FL en l'individu?}

Les cries humanes no neixen parlant. Que això sigui una obvietat no significa que no sigui alhora una observació rellevant, atès el fet que els infants, eventualment, sí que són capaços de parlar i, per tant, que alguna cosa passa en les seves ments/cervells que fa que això sigui possible. No importa quina sigui la vostra posició filosòfica favorita, el cas és que cal donar una explicació sobre com els infants aprenen, adquireixen o desenvolupen les seves destreses lingüístiques. Escolliu el terme que 
preferiu per descriure aquest procés. Personalment, prefereixo parlar de desenvolupament, pero no és aquest el moment de barallar-se per subtileses com aquesta. Una altra obvietat lligada al problema del desenvolupament del llenguatge té a veure amb el fet que tots els humans són capaços d'adquirir com a mínim una llengua però no estan determinats a adquirir una llengua concreta. En contra del que puguin sostenir certes ideologies xenòfobes, racistes i d'ultra dreta, tots els humans neixen iguals, al menys pel que fa a llurs capacitats lingüístiques. En altres paraules, néixer a la zona occidental d'Uganda, a la riba del llac Albert, no determina un infant a ser parlant del nyoro com tampoc haver nascut a la Turquia oriental, a la riba del llac Van, no determina un infant a ser parlant de l'armeni. Com a molt, aquestes circumstàncies poden jugar un paper important com a factors contextuals rellevants per explicar quina llengua acabaran desenvolupant els nostres infants, pero en cap cas com a factors determinants. De fet, si per acció d'algun sistema màgic de teletransport s'emboliqués la troca i l'infant nascut a l'Armènia turca s'intercanviés amb l'infant nascut a Uganda, el més probable és que el primer acabés parlant nyoro i, el segon, armeni, és a dir, les llengües que formen part del seu nou entorn. Patologies apart, ser parlant és una condició necessària per a tot humà, ${ }^{11}$ però ser parlant de és contingent.

\section{Per què hi ha tantes llengües?}

Això és el que, més apropiadament, es coneix com el problema de la variació. El problema de la variació és, de fet, dos problemes camuflats sota un únic terme paraigua. El primer dels problemes és el que més s'acosta a allò que suggereix la pregunta que encapçala aquest paràgraf i el podríem formular així:

a) si la FL té alguna cosa a veure amb la nostra dotació biològica en tant que membres de l'espècie Homo sapiens, llavors

\footnotetext{
11 On el terme 'parlant' no s'ha d'entendre en aquest context en el sentit d"usuari d'una llengua a través del canal oral-auditiu', ja que els usuaris de les llengües de signes són també 'parlants' en el sentit que uso el terme en el text. Seguiu els enllaços si voleu saber més sobre les llengües de signes en general i la catalana en particular.
} 
b) la FL o, en tot cas, aquell estat de la FL que fa possible que els bebès humans desenvolupin destreses lingüístiques, ha de ser relativament uniforme per a tots els individus de l'espècie (recordeu el nostre experiment mental amb l'infant ugandès i l'infant armeni del paràgraf anterior); però, llavors,

c) com és que hi ha tantes llengües?

Aquesta darrera pregunta té un una faceta interessant i una d'estúpida. La vessant estúpida té sobretot a veure amb la mena d'afirmacions estúpides que certes persones estúpides fan sobre la utilitat de les llengües en tant que eines de comunicació. L’observació estúpida per excel·lència es aquesta: ${ }^{12}$

- Per què t'entestes a seguir parlant <inseriu aquí el nom d'una llengua minoritària o minoritzada com ara: català, gallec, basc, amazig, occità, sicilià >, si és una <inseriu aquí alguna expressió desdenyosa com ara: merda, vulgaritat, ximpleria, cosa d'analfabets $>$ ? Les llengües serveixen per comunicar-se $i$ tot ens aniria molt millor si tothom parlés <inseriu aquí el nom d'una llengua majoritària com ara: anglès, castellà, francès, mandarí>.

No penso perdre el temps a rebatre una actitud tan estúpida com aquesta. Em limitaré a dir una cosa: apreneu tantes llengües com vulgueu (no fa mal), però mai no renuncieu al dret de parlar la vostra llengua (o llengües) i mai no forceu ningú a abdicar del seu dret a parlar la seva llengua (o llengües)-aquestes dues darreres coses sí que fan mal. En general, aquells qui veuen un problema en la variació, des de la perspectiva de la presumpta utilitat de la llengua en tant que sistema de comunicació, acostumen a pensar estupideses com aquestes. Evidentment, des d'una perspectiva eminentment utilitarista, amb una, i només una, llengua en tindríem prou, però em sembla que ja he suggerit en més d'una ocasió que l'utilitarisme és,

\footnotetext{
12 Típicament expressada per parlants monolingües de llengües majoritàries que, també típicament, acostumen a ser uns ineptes en el moment de parlar una llengua que no sigui la pròpia, fins i tot aquelles que, segons sostenen aquests parlants monolingües d'una llengua majoritària, se suposa que són tan útils que tothom hauria de parlar-les.
} 
gairebé sempre, estúpid i, per tant, no és aquesta la mena de qüestió que volem tractar en relació amb el problema de la variació. ${ }^{13}$

La qüestió, tanmateix, va adquirint interès quan ens adonem que la formulació de la pregunta en forma de 'per què' oculta, de fet, la recerca d'un 'com'. Una cosa així: com canvien les llengües? No cal un temps de reflexió gaire llarg per adonar-se que aquesta pregunta s'assembla molt a una pregunta que Darwin i molts altres biòlegs dels segles XVIII i XIX van intentar respondre apel-lant a la idea d'evolució i als mecanismes que la fan possible. Els mecanismes, és clar, són la clau de volta de qualsevol teoria evolutiva, ja que, com molt encertadament va observar Karl Ernst von Baer en la seva ressenya de l'Origen de les espècies de Darwin, "el supòsit que les diferents espècies d'animals s'han desenvolupat les unes a partir de les altres és tan obvi i natural que ha d'haver aparegut molt aviat"; ${ }^{14}$ evidentment, la part més difícil és identificar el mecanisme (o mecanismes) de l'evolució. És ben sabut que Darwin assenyalà la Selecció Natural com a principal mecanisme dels processos evolutius (no l'únic), però va lluitar tota la seva vida per intentar desvelar el secret dels mecanismes subjacents a allò sobre el que la Selecció Natural necessàriament actua: la variació-no hi ha selecció possible quan no hi ha opcions on triar, oi? Aquesta breu excursió en el camp de la biologia evolutiva hauria de servir per veure que l'estudi de la variació lingüística s'enfronta a problemes similars als que intenta resoldre l'estudi de la variació biològica i que en tots dos casos hi ha una relació molt estreta amb la necessitat d'entendre el canvi (lingüístic o biològic). Tornant, si m'ho

\footnotetext{
13 En aquest punt, pot ser que alguns de vosaltres esteu pensant en l'esperanto i em temo que hauré de dir alguna cosa sobre això. Per molt romàntic, utòpic i fraternal que pugui semblar el somni dels esperantistes d'acabar amb els conflictes del món precisament a través de l'adopció d’una llengua supranacional que esborrés les diferències entre nacions, cal notar, per una banda, que aquest somni està basat, precisament, en la mena de pensament utilitarista que tot just acabo de criticar (en la seva vessant fraternal, si voleu); per una altra banda, està basat en una idea que va en contra de tota l'evidència que tenim sobre com les llengües muten al llarg del temps. En altres paraules, la idea d'una llengua estàtica, immutable, la mateixa per a tots els membres de l'espècie humana és, sí, una utopia, però no com la Utopia de Thomas More, sinó més aviat com el somni de poder volar, d'esdevenir immortal o alguna cosa d'aquest estil. Com de seguida veurem, les llengües canvien i és inevitable que sigui així: és impossible aturar-les en aquest procés de canvi i, l'esperanto, si algun dia arribés a imposar-se, també canviaria i s'aniria diversificant en moltes variants noves fins a fer-se irreconeixible.
}

$14<$ Die Vermutung, daß die einzelnen Thierarten aus einander sich entwickelt haben, ist so naheliegend und natürlich, daß sie schon sehr früh auftreten mußte.>> Karl Ernst von Baer. 1876. Ueber Darwin's Lehre. Dins Reden gehalten in wissenschaftlichen Versammlungen und kleinere Aufsätze vermischten Inhalts. Zweiter Theil. Karl Röttger, St. Petersburg, pp. 261-506; el fragment citat és a la pàgina 279. 
permeteu, a Darwin, val a dir que tot i que va ser incapaç d'explicar els mecanismes de la variació, això no li va impedir d'assumir que en la natura s'anava introduint constantment nova variació i que una part d'aquesta variació present en els progenitors era a més a més heretable per llurs descendents. Fins a aquí, tot sembla prou raonable, però Darwin, en l'últim paràgraf de l'Origen, ${ }^{15}$ també va suggerir que la variació és potencialment il-limitada, sense restriccions. Similarment, en lingüística hi ha una llarga tradició, generalment vinculada a l'Estructuralisme Americà (però no només), que ha assumit que les llengües poden "diferir les unes de les altres sense límit i de manera impredictible”, la qual cosa, adoptant potser una actitud encara més radical que la de Darwin, explícitament ens convida a no voler anar més enllà d'allò que és observable, per intentar cercar explicacions d'un fenomen que, com a molt, ens podem limitar a constatar. Crec que, en aquest cas, la citació mereix quelcom més que una nota al peu; és aquesta:

Trubetzkoy phonology tried to explain everything from articulatory acoustics and a minimum set of phonological laws taken as essentially valid for all languages alike, flatly contradicting the American (Boas) tradition that languages could differ from each other without limit and in unpredictable ways, and offering too much of a phonological explanation where a sober taxonomy would serve as well.16 [Les paraules subratllades apareixen així en l'original; la cursiva és meva.]

\footnotetext{
15 Per si de cas, el famós paràgraf és aquest:

$<<$ There is grandeur in this view of life, with its several powers, having been originally breathed into a few forms or into one; and that, whilst this planet has gone cycling on according to the fixed law of gravity, from so simple a beginnig endless forms most beautiful and most wonderful have been and are being, evolved.>>

on n'he subratllat les paraules clau. Si voleu llegir aquest mateix paràgraf tal i com apareix en la primera (o en qualsevol altra) edició de l'Origen, podeu visitar el web Darwin Online, on hi trobareu aquest i molts altres textos del biòleg anglès.

$16<<$ La fonologia de Trubetskoi intentava explicar-ho tot a partir de l'acústica articulatòria i d'un conjunt mínim de lleis fonològiques enteses com a essencialment vàlides per a totes les llengües, en plena contradicció amb la tradició americana (Boas) segons la qual les llengües poden diferir entre elles sense límits i de manera impredictible, tot oferint un excés d'explicació fonològica allà on una sòbria taxonomia hauria fet la mateixa feina. >>
} 
Les paraules pertanyen al lingüista nordamericà Martin Joos i van ser escrites el 1958. ${ }^{17}$ He posat en cursiva la darrera frase perquè us feu una idea del que comporta aquesta visió de la lingüística com a entomologia que va dominar la disciplina durant bona part de la primera meitat del segle XX.

Sí, hi estic d'acord, si això és la lingüística, llavors és molt avorrida; l'entomologia és més divertida. Ara, però, feu l'exercici de considerar que, potser, Joos estava equivocat, que, potser, sí que hi ha mecanismes subjacents a la variació i que, per tant, la variació lingüística no és tan caòtica com ens volia fer pensar la tradició nordamericana. ${ }^{18}$ Un cop fet aquest pas, una conseqüència immediata és que comencen a plantejar-se noves preguntes. Per exemple: hi ha restriccions sobre la variació? O, dit d'una altra manera, és possible establir trets possibles i impossibles en l'estructura i l'organització de les llengües? Hi ha un límit pel que fa al nombre de llengües possibles?

És moment de tornar a mirar cap a la biologia. El fracàs de Darwin en el seu intent de construir una teoria de la variació no va desanimar els seus seguidors i, de fet, la biologia contemporània té avui en dia una idea prou clara de com hauria de ser aquesta teoria. Per exemple, ara està prou clar que la variació té alguna cosa a veure amb la diversitat genètica $\mathrm{i}$ amb la manera com aquesta diversitat genètica es tradueix en caràcters biològics a través dels processos de desenvolupament en el context de les circumstàncies ecològiques en què està immers l'organisme. Encara més important, també és prou clar que no val tot, que hi ha restriccions molt fortes sobre allò que pot produir un procés de desenvolupament; en altres paraules, hi ha animals (i plantes) possibles i impossibles. Els àngels són éssers impossibles, per

\footnotetext{
17 Per ser precisos, la cita prové dels comentaris de Joos a un article de Bernard Bloch titulat 'Phonemic Overlapping' i publicat dins Martin Joos, ed. 1958. Readings in Linguistics. The Development of Descriptive Linguistics in America since 1925. New York: American Council of Learned Societies, pp. 93-96. El fragment en qüestió és a la pàgina 96 del llibre que, per a aquells a qui els agrada consultar les fonts originals, és accessible en lína.

18 Per cert, el nom entre parèntesi que apareix en la cita de Joos fa referència a l'antropòleg Franz Boas qui, entre moltres altres coses, va fomentar l'estudi de les llengües natives de Nordamèrica (alguna cosa bona havia de sortir d'aquesta tradició). Per la seva banda, 'Trubetzkoy' fa referència al príncep Nikolai Serguéievitx Trubetskoi, un dels fundadors de la fonologia i la morfologia contemporànies.
} 
exemple, perquè a cap humà mai no li creixeran unes ales a l'esquena-hi ha restriccions estructurals sobre com es pot construir un esquelet vertebrat que ho impedeixen. Malauradament, el humans mai no podrem volar, però, perquè encara que les nostres mans (com ha passat amb els ratpenats) o els nostres braços (com ha passat amb els ocells) es tornessin ales, resulta que hi ha restriccions físiques sobre les dimensions que pot tenir un animal volador-els humans som massa grossos. Un humà amb sis extremitats, però, sí que seria biològicament possible, però és altament improbable (virtualment impossible) que això esdevingui una realitat-hi ha restriccions històriques sobre les formes animals i el patró quatre pel que fa a les extremitats dels vertebrats és tan antic i està tan arrelat que l'emergència de nous patrons possibles però inexistents és, com deia, un esdeveniment amb una probabilitat pròxima a zero.

Fixem-nos ara en les llengües i preguntem-nos si hi ha restriccions estructurals, físiques i històriques que condicionin com pot ser una llengua humana. Aquest és, de fet, el segon problema a què em referia abans, al principi d'aquesta subsecció, que mereix el títol d'El Problema de la Variació' i que, si hi penseu, és potser el més interessant dels dos. Només uns breus moments de reflexió ens revelaran que, efectivament, hi ha diverses restriccions del tres tipus. Per exemple, en tant que fenòmens físics, els sons poden ser molt diferents, però la nostra oïda és només capaç de copsar sons dins d'un ventall específic, per tant és prou raonable suposar que l'estructura fonètica de les llengües s'ajusti a aquest ventall i que no varï sense límits: hi ha, sense cap mena de dubte, restriccions físiques sobre què pot ser un so possible en una llengua. Similarment, el nostre sistema articulatori no és capaç de produir qualsevol so físicament possible i, per tant, hem d'assumir que també hi ha restriccions estructurals sobre els tipus de sons que poden formar part de l'inventari de sons d'una llengua. Finalment, no hi ha cap llengua que situï la partícula negativa en la cinquena posició d'una frase, tot i que comptar fins a cinc clarament entra dins 
de les nostres capacitats cognitives: aquest podria ser un exemple de restricció històrica, un patró que és perfectament possible però, per ara, inexistent.19

Tornant doncs al principi: per què hi ha tantes llengües? Evidentment perquè canvien. I, com canvien? Bé, doncs, això no ho sabem exactament, però és clar que una teoría del canvi lingüístic no serà molt diferent d'una teoria del canvi biològic. Aquesta inclouria, com a mínim, un model del mecanisme (o dels mecanismes) com es genera variació (dins d'uns límits, és clar) i un model del mecanisme (o dels mecanismes) de selecció de les variants en competició. Pel que fa al primer, no hi ha cap mena de dubte, la nostra teoria de l'adquisició del llenguatge hi tindrà molt a dir, ja que el procés de transmissió de pares a fills és un element clau en la història causal que volguem explicar sobre la producció de variació. Pel que fa al segon, incorporarà, sobretot, una anàlisi dels factors socials, cognitius i culturals que fan que els parlants escullin (de manera conscient o inconscient) unes variants o unes altres. Sigui com sigui, qualsevol teoria del canvi lingüístic haurà d'afrontar tard o d'hora el problema de què canvia quan canvia una llengua $i$, perquè això sigui possible, cal tenir una idea més o menys clara de què és la FL i com està organitzada.

\section{La lingüística en acció}

En el capítol anterior m'he ocupat de presentar les principals preguntes que qualsevol teoria general del llenguatge ha de mirar de respondre. Allà hem vist que, tard o d'hora (més d'hora que tard, a ser possible), qui estigui interessat a respondre aquestes preguntes haurà d'afrontar el problema de la FL. He usat la paraula 'problema' expressament, perquè l'estudi de la FL planteja tota una colla de desafiaments que haurem d'encarar d'una manera o d'una altra. El primer i principal és el de determinar quina mena de dades empíriques són rellevants per a la nostra investigació i com han de ser interpretades. En aquest context, és convenient remarcar, per obvi que sigui, que la FL no és directament observable i, per tant,

\footnotetext{
${ }^{19} \mathrm{Hi}$ ha llengües, com el macedoni, l'eslovè o l'ucraïnès, que situen la negació en la segona posició dins la frase, llavors, per què no en la cinquena?
} 
haurem d'imaginar estratègies que ens permetin de detectar-ne les propietats a través de mitjans indirectes. Això presenta alguns problemes de mètode.

\subsection{Qüestions de mètode}

És en relació amb consideracions com les que feia al final de paràgraf anterior que la qüestió de les dades esdevé particularment rellevant. No hi ha dubte que una de les nostres principals fonts de dades empíriques serà la conducta lingüística dels parlants i, com espero demostrar en aquesta secció, podem arribar prou lluny prestant especial atenció a allò que diu la gent i, molt especialment, a com ho diu. No cal dir que també ens calen eines teòriques específiques per analitzar aquestes dades, ja que la mera observació gairebé mai resulta útil quan es tracta de comprendre la natura: les balenes i els dofins semblen peixos, però tothom sap (o hauria de saber) que són mamífers. La teoria i l'observació dirigida per la teoria són ineludibles quan es fa ciència. Ja he fet esment del fet que les dades procedents de l'observació de la conducta lingüística són una de les nostres principals fonts, però ara he d'afegir que no l'única. Hi ha una altra font, molt important, d'informació en el que podríem caracteritzar com a dades artificials o, en altres paraules, dades fabricades que no provenen necessàriament de l'observació. Com que això probablement us sona a fer trampes, cal que dediqui una mica d'espai a explicar aquesta idea.

La qüestió té a veure amb un problema ben conegut en el camp de la filosofia de la ciència anomenat El Problema de la Inducció, que podem il-lustrar amb un exemple clàssic. ${ }^{20}$ L'exemple és aquest: imagineu que sou ornitòlegs o, simplement, aficionats a observar els ocells i que, a tal efecte, sovint sortiu d'excursió pel camp. En les vostres sortides, us topeu amb certa freqüència amb un ocell de dimensions notables que viu en llacs i estanys i que no havíeu vist fins ara. Com que teniu una certa experiència en avistaments d'aus aquàtiques, observeu que s'assembla a un

\footnotetext{
20 Tradicinalment, el nom que s’associa amb el Problema de la Inducció és el del filòsof escocès David Hume, un filòsof que-potser ex aequo amb Descartes-mereix el premi de posar el dit a la llaga al respecte de nombrosos problemes per al quals encara no hem sabut trobar una solució satisfactòria.
} 
ànec, però clarament no és un ànec: és més gros, té el coll molt llarg i, a diferència dels ànecs, no semblar existir una diferència clara en la coloració del plumatge de mascles i femelles-tant els uns com les altres són blancs amb el bec negre-groc. Finalment, decidiu de posar-li nom a aquest nou exemplar d'ocell que heu descobert i li dieu 'cigne'. També, i fruit de les ja moltes ocasions en què heu tingut l'oportunitat d'observar-los, concloeu que 'Tots els cignes són blancs'. Col-loquialment, d'això potser en diríem una deducció, però no ho és; de fet, és quelcom de molt diferent. Noteu que el que heu fet és, a partir d'una sèrie d'observacions particulars en les quals hi havia cignes, generalitzar $i$ conjecturar que tots els cignes són blancs sense tanmateix haver vist tots els cignes, la qual cosa és impossible. La vostra és el que s'anomena una inferència inductiva $\mathrm{i}$, en general, hom considera que és molt més feble que altres tipus possibles d'inferències, sobretot perquè és cancel-lable. La vostra teoria sobre els cignes blancs és, de fet, la mateixa que tenien tots els naturalistes fins més o menys 1790 , moment en què va començar la colonització d'Austràlia: resulta que els cignes australians són negres i tenen el bec vermell. No és que les inferències inductives siguin dolentes en si mateixes, sovint no tenim altra possibilitat, però el fet que siguin potencialment cancel-lables cada vegada que tenim informació nova sobre el fenomen ha fet que els científics hagin cercat metodologies per fer més robustes llurs teories. Tornant als cignes, què hauria passat si els cignes negres d'Austràlia s'haguessin extingit, com de fet va passar amb els seus cosins de Nova Zelanda que, pel que sembla, també eren negres? Doncs que la nostra teoria sobre els cignes quedaria irremediablement incompleta i, això, no els agrada als científics. El que els agrada als científics és poder dir coses com ara que 'els cignes poden ser blancs o negres, però no poden ser ni verds ni vermells', per exemple. Noteu que la segona part d'aquesta afirmació mai no pot derivar-se de l'observació directa dels cignes, perquè no hi ha cignes verds ni cignes vermells, sinó que només pot deduir-se a partir d'alguna llei-o principi o restricció-general sobre la coloració del plumatge dels cignes. Potser en aquest cas en particular estiguem davant d'una restricció històrica, de tal manera que en un futur no gaire llunyà podria aparèixer una nova espècie de cigne verd, vés a saber; o potser és una restricció estructural i hi ha alguna cosa en la naturalesa dels cignes que els impedeix ser de color verd. Com en el cas anterior, no ho sabem (jo no ho sé, al menys). Però crec que ara es veu prou 
clar on volia arribar: allò que és impossible no és observable però pot ser tant rellevant o més que allò que és observable en el moment de construir una teoria.

La lingüística, en això, no és (o no hauria de ser) diferent de qualsevol altra ciència. Podem aprendre molt sobre el llenguatge a partir de l'observació directa, però també ens cal una manera d’identificar els equivalents lingüístics dels cinges negres i dels cignes verds: volem destriar aquelles coses que fins ara no hem observat però són possibles d'aquelles coses que no hem observat ni observarem mai perquè són impossibles. Aquest és el paper de les dades artificials. Aquest tipus de dades no són, per tant, dades falsificades, ${ }^{21}$ són només coses imaginables (com un cigne negre o un cigne verd) que volem saber si, a més a més d'imaginables, són o poden ser reals. I, com ho fem, això? Fàcil, només cal preguntar. Preguntar als parlants, és clar, perquè els parlants (nosaltres inclosos) són autoritat. Recordeu-ho, la lingüística no és una disciplina normativa i el principi següent sempre ha de prevaldre per sobre de tot: si algú ho pot dir, llavors és possible. Pot donar-se el cas, sí, que vagi en contra d'alguna norma establerta, doncs pitjor per la norma; o, potser, vagi en contra del que prediu la nostra teoria, doncs, llàstima, pitjor per la teoria perquè caldrà modificar-la.

Ara mateix seria prematur donar-vos exemples de dades artificials, perquè per construir-les cal un cert grau de sofisticació analítica que hom només adquireix fent lingüística. No obstant això, n'hi ha prou amb dir, com ja apuntava cap al final de la secció anterior, que sí que hi ha coses impossibles, coses que ningú no pot dir, en cap llengua. Però coses com aquestes només podem arribar a saber-les si recorrem a dades fabricades, imaginades, que presentem als parlants i siguin els propis parlants que les judgin i avaluïn. Aquests judicis són molt valuosos, ja que són una de les nostres principals finestres a la FL. Per què això és així és prou clar: si posseir una FL és un dels trets que ens fa humans, llavors tothom té una FL; per tant, quan un parlant es troba davant de dades lingüístiques que ha d'avaluar, està, encara que sigui de manera inconscient, fent servir la seva FL i nosaltres podem descobrir-ne

\footnotetext{
21 Alguns lingüistes de corda ultraempirista sí que pensen que són dades falses o tramposes, però en ciència, com en la vida, un sempre s'acaba topant, tard o d'hora, amb algun fanàtic.
} 
alguna cosa de manera indirecta, a partir de l'observació de la conducta del nostre informant quan s'enfrota a dades artificials.

El que us proposo en la propera subsecció és precisament això, que fem servir la nostra FL, a veure si podem descobrir quelcom d’interessant.

\subsection{Finestres a la FL}

A la Secció 2.1 ja hem fet un exercici que s'acosta molt a aquesta idea de posar en funcionament la nostra FL i que aquí explotarem al màxim. Recordeu l'experiment mental que allà us proposava i que em va permetre de dibuixar la figura [2], que ara tornaré a dibuixar, per tenir-la més a prop, com a figura [3].

Ara, el que vull fer és el següent: prenent aquesta figura com a punt de partida, vull veure si podem afegir algun dels (molts) detalls que manquen. En particular, vull veure si podem trobar alguna manera de veure quelcom dins la caixa negra. Els principis que seguiré seran els mateixos que abans: apel-laré a les vostres intuïcions lingüístiques per forçar-vos a usar la vostra FL i, així, donar lloc a conductes i judicis que, esperem-ho, aportin alguna llum i comencin a dissipar la boira negra que envolta la caixa. Tornant, doncs, a l'escenari original, proposo primerament de fer un zoom per tal de seguir l'estímul sonor en el seu viatge dins l'orella. Els detalls anatòmics i fisiològics són, per ara, irrellevants, el que és important és que comprengueu que l'estímul com a tal acaba el seu periple ben aviat, concretament en l'orella interna, on l'espera en MAS; figura [4]. MAS significa Mòdul d'Anàlisi del Senyal i passarem un mica de temps amb ell, ja que ha arribat el moment en què ja no podem defugir de parlar de percepció. 


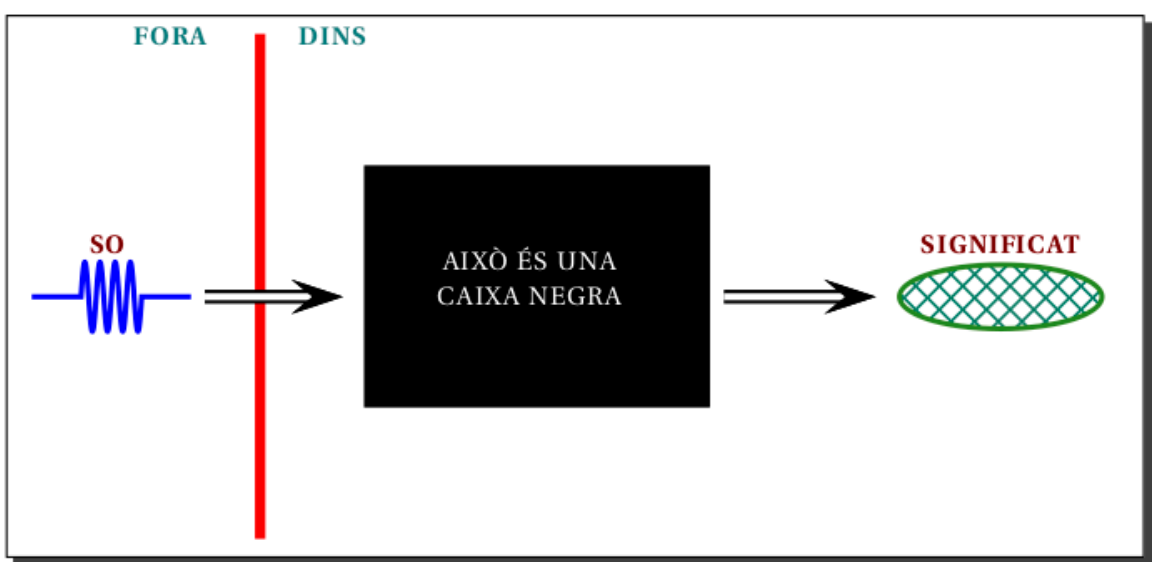

Figura 3: Una primera aproximació a respondre com arribem a entendre allò que ha dit el nostre interlocutor.

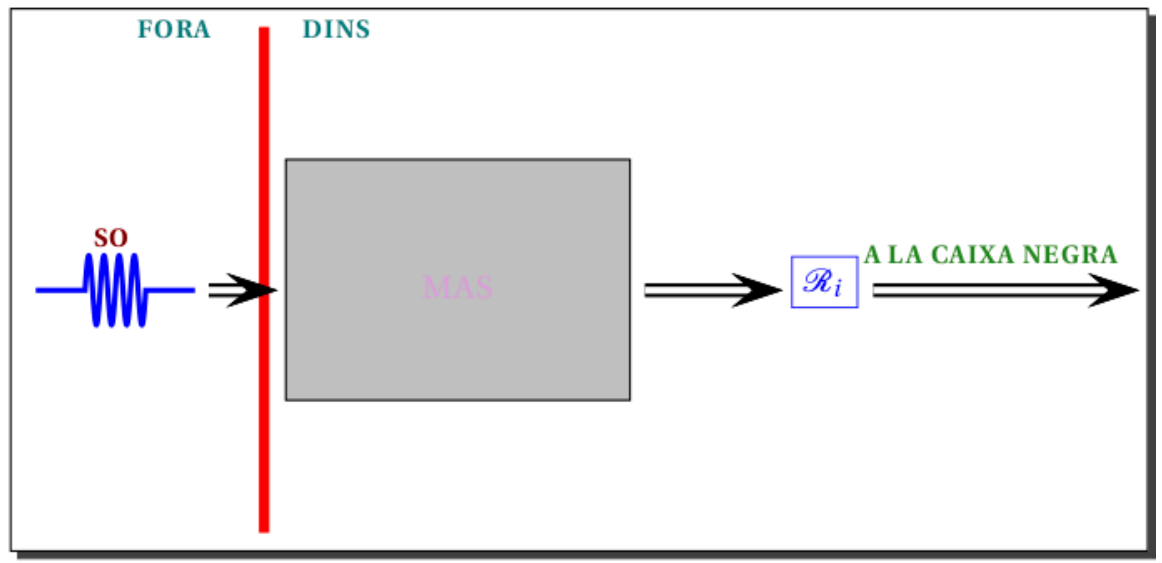

Figura 4: Segona aproximació a intentar respondre com arribem a entendre allò que ha dit el nostre interlocutor: anàlisi del senyal i representació.

En el nostre cervell no hi ha músiques ni imatges, ni colors ni formes. Quan percebem una pilota vermella, per exemple, aquest estímul no provoca l'emergència en les nostres ments/cervells d'una rèplica minúscula, però fidel, d'una pilota vermella. Per absurda que us sembli aquesta teoria de la percepció, ${ }^{22}$ val a dir que, no obstant això, ja conté un element que serà fonamental en l'argument que estic a

\footnotetext{
${ }^{22}$ A grans trets, aquesta és la teoría de la percepció d'Aristòtil que, en essència, està basada en la idea que els objectes de la percepció tenen el poder de modelar la substància mental a través d'allò que Aristòtil anomenava 'qualitats secundàries' (coses com el color o la forma, per exemple). D'acord amb això, quan veiem una pilota vermella, les seves qualitats secundàries esculpeixen la substància mental com si aquesta fos argila o cera. Com podeu imaginar, l'ontologia d'Aristòtil és bastant rica.
} 
punt de construir. El que m’interessa destacar aquí és la clara distinció que ja s'estableix entre l'objecte de la percepció (la pilota vermella que estem veient) i el percepte que n'és l'efecte (la petita pilota vermella dins del nostre cap). Per tant, malgrat que la teoria aristotèlica de la percepció és un cas perdut, ens permet d'esbossar el que seria l'esquema bàsic de com hauria de ser un model general de la percepció: el cervell, després de rebre un estímul (visual, auditiu, etc.) a través dels sentits, és capaç de construir una representació d'aquest estímul a partir de l'anàlisi de les seves propietats físiques (en aquest cas concret, la longitud d'ona, la intensitat, etc.). Això és el que fa en MAS: analitzar les propietats físiques de l'estímul acústic i, amb aquesta informació, en construeix una representació-la $\mathcal{R}_{i}$ blava de la figura 4 . Com us podeu imaginar, el rovell de l'ou de la qüestió és el concepte de representació. La paraula 'representació' té dues accepcions, ja que pot designar una entitat o un acte: les representacions representen alguna cosa però no són aquella cosa-la representació d'una pilota vermella no és la pilota vermella (i, amb tota seguretat, tampoc no és una pilota vermella). La relació de representació que existeix entre la representació i la cosa representada és una relació d'intencionalitat o semàntica, que potser és un terme més clar: les representacions tracten sobre les entitats que representen.23 Per tant, l'entitat simbolitzada amb una $\mathcal{R}_{i}$ a la figura 4 tracta sobre el so en el sentit que conté informació relacionada amb el so. Abans de seguir endavant, un avís: ningú no ha vist mai una representació, les representacions són constructes teòrics l'existència dels quals assumim perquè, a dia d'avui, són la millor (si no l'única) explicació que tenim sobre com els organismes interactuen amb el món. Com ja suggereix la referència a Aristòtil, el supòsit té una llarga tradició i el trobareu en diverses formes i pelatges en la filosofia de Hobbes, de Descartes, de Leibniz, de Locke, de Hume o de Kant, per citar només alguns noms, tot i que s'hi acostuma a fer referència de forma genèrica amb l'expressió Teoria de les Idees. Si

\footnotetext{
23 He d'admetre que la terminologia és una mica confusa i potser cal alguna explicació addicional. El terme 'intencionalitat', tal i com l'he usat aquí, és un terme tècnic usat en filosofia amb el sentit d'apuntar o assenyalar cap a una diana o un objectiu (del llatí intendere, 'tendir cap a, extendre, dirigir'), és a dir que la relació de representació és intencional en la mesura que la representació apunta o assenyala la cosa representada, la representació tracta d'aquella cosa; en anglès, sovint s'usa el terme sinònim aboutness. Per tant, podem dir que la relació és semàntica perquè, en un cert sentit, la representació té significat en virtud del fet que manté la relació que manté amb l'objecte representat. Les coses són molt més complexes, però, a grans trets, la idea és aquesta.
} 
hagués de citar un punt en el qual, primer els filòsofs i, després, els psicòlegs i altres investigadors en el camp de les ciències cognitives (els lingüístes inclosos) semblen estar d'acord és aquest: hi ha representacions (o idees). ${ }^{24}$

Arribats a quest punt, podem plantejar-nos algunes preguntes interessants sobre la representació $\mathcal{R}_{i}$ de la figura 4; per exemple, com és o, si ho preferiu, com representa $\mathcal{R}_{i}$ l'estímul acústic? Aquesta és una pregunta sobre el format de la representació o, en altres paraules, sobre com captura la representació les propietats rellevants de l'estímul. Si rumieu la qüestió una estona, aviat veureu que no hi ha gaire maneres de representar una cosa. Una és, precisament, fer-ho a la manera d'Aristòtil, és a dir, construint una rèplica de l'objecte representat, però aquesta opció ja l'hem descartada. Una altra consisteix a fer-ne una imatge: les pintures, els dibuixos, les fotografies, etc., són maneres prou efectives de representar objectes sense necessitat de construir models en miniatura-una imatge acostuma a ser en $2 \mathrm{D}$, però pot fàcilment copsar que l'objecte és en $3 \mathrm{D}$ (a través de la perspectiva, per exemple). Aquesta és la noció de representació que trobareu en la teoria de les idees de Locke, Berkeley o Hume, però hi ha motius prou sòlids per pensar que els nostres cervells no construeixen imatges mentals/cerebrals i un d'aquests motius és que, tot i que les imatges són perfectes per representar certes coses, es troben amb enormes dificultats quan es tracta de representar-ne d'altres, de coses-quina és la representació pictòrica de l'amor? Com podem representar un so amb una imatge? Noteu que la resposta mès òbvia a aquestes dues preguntes és la mateixa: amb un símbol. Per tant, sembla que la solució més raonable per a una teoria general de les representacions (mentals) és, seguint Hobbes i Descartes, assumir que són alguna

\footnotetext{
${ }_{24}$ Com sempre passa, el consens no és mai absolut $i$, de fet, hi ha un corrent de pensament relativament recent que es defineix a si mateix com a antirepresentacionalista. De tota manera, convé aclarir que l'antirepresentacionalisme no es ben bé un posicionament ontològic, sinó més aviat metodològic, ja que la majoria de persones que s'hi han adherit acostumen a defensar que és possible explicar el mateix que expliquen els representacionalistes sense necessitat d'apel-lar a les representacions. A la llarga, però, resulta dubtós que aquest agnosticisme pel que fa a l'existència de representacions pugui mantenir-se gaire temps sense topar-se amb problemes molt seriosos, ja que tendeix a desmoronar-se tan aviat com aquest problemes es presenten, i el del llenguatge és un d'ells. Els antirepresentacionalistes, per regla general, acostumen a centrar la seva atenció en conductes molt simples, com les dels insectes, amb la idea que, a partir d'aquí, hauria de ser possible anar construint-ne de més complexes i basades en capacitats cognitives superiors. En aquest context, doncs, tot i que probablement és cert que no cal una ontologia gaire rica quan es tracta d'explicar la conducta deambulatòria d'una marieta, està per veure que hom pugui sostenir la mateixa postura quan es tracta d'explicar la conducta d'un mamífer.
} 
mena de símbols. En qualsevol cas, ningú fins ara ha sabut oferir una alternativa seriosa a aquest supòsit. Acceptarem, doncs, que $\mathcal{R}_{i}$ és la representació d'un so en format simbòlic. Podem dir alguna cosa més, per exemple, sobre la seva estructura? Sí, i tant que podem. Ha arribat el moment de dur a terme un petit experiment psicolingüístic.

Quants sons diríeu que conté la paraula catalana 'tassa'? Alerta, perquè he dit sons, no lletres. La meva pregunta té a veure amb com pronuncieu la paraula i no amb com l'escriviu. La paraula 'tassa' té cinc lletres, però això no vol dir que necessàriament, quan hom la pronuncia, també tingui cinc sons. Preneu-vos el temps que calgui per buscar una resposta.

Llestos? Molt bé, doncs, independentment de quina varietat del català parleu (aquesta variable és irrellevant en aquest cas), a continuació teniu dues possibles respostes:

(a) Quatre: [tasə], i.e. [t] ,[a],[s], i [ə] .

(b) Dos: [tasə], i.e. [ta] I [sə] .

Potser hi ha altres respostes, però a mi no se me n'acuden gaires més. Coincideixen aquestes respostes amb les vostres intuïcions? Confio que sí. Tant és si la vostra resposta hauria estat la (a) o la (b); la idea que vull defensar funciona en tots dos casos.

I la idea és aquesta: sembla que pensem en les paraules en termes d'arrenjaments d'unitats ordenades linealment en una seqüència temporal. Atenció perquè aquesta és una intuïció-prou robusta, sí-sobre com percebem els sons, la qual cosa no vol dir que l'estímul tingui realment aquesta estructura. En aquesta mena d'experiments sobre percepció és molt important adonar-se que les intuïcions només poden fer referència a les propietats dels perceptes (i.e. les representacions), però no a les propietats dels estímuls, ja que gairebé mai es dóna el cas que la nostra representació 
del món sigui una reproducció fidel de com és realment aquest món. ${ }^{25}$ No hi ha dubte que aquesta afirmació caldria precisar-la, però ni tinc espai per fer-ho ni és imprescindible per mantenir que la nostra idea sobre què és una paraula s'acosta molt a la d'una seqüència lineal de símbols, una idea, per altra banda, prou robusta i prou antiga, com ens demostra la història del desenvolupament dels sistemes d'escriptura. ${ }^{26}$ Per tant, consideraré que això és evidència suficient per assumir que $\mathcal{R}_{i}$ codifica les propietats fonètiques dels estímuls lingüístics en forma de seqüències d'unitats discretes ordenades temporalment, de tal manera que cadascuna d'aquestes unitats es correspon amb exemplars d'allò que nosaltres conceptualitzem com a un únic so de la llengua, com per exemple [ə] (l'anomenada 'vocal neutra'). Hi ha moltes maneres de representar això sobre el paper, a mi m'agrada fer-ho com a (1), però sou lliures d’imaginar maneres alternatives d'il-lustrar una representació fonètica; l'única condició és que hi quedin reflectits certs elements bàsics de la seva estructura, com ara el caràcter discret de les unitats i la seqüència temporal.

(1)

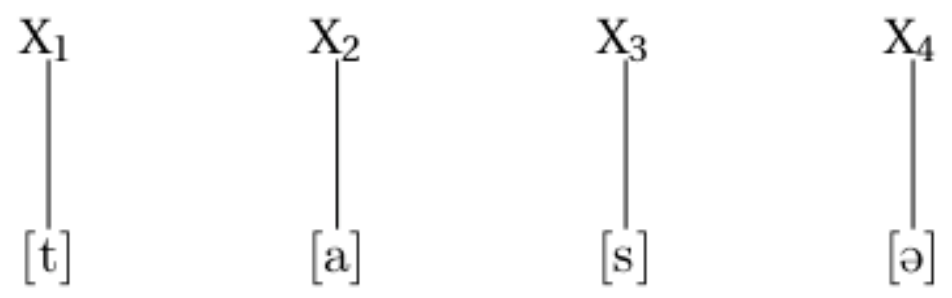

La idea d'(1) és que hi ha un esquelet d'unitats temporals (les X amb subíndexs) i que amb cada una hi tenim associat l'exemplar d'un so (d'ací les línees verticals), però, com ja he dit, qualsevol altra convenció pot funcionar: finalment, no sabem realment com són aquestes representacions-no podem veure-les, només podem

\footnotetext{
25 Això és particularment clar en el cas dels colors, ja que ‘tenir color’ no és una propietat de la matèria i allò que nosaltres percebem com a colors no és altra cosa que la llum reflectida per la superfície dels objectes a diferents freqüències i longituds d'ona. Així, quan veiem una pilota vermella, aquesta sensació és una funció de la llum a baixa freqüència que incideix sobre els receptors de llum de la nostra retina i de la manera com el nostre cervell processa aquesta informació. Si voleu saber més sobre la percepció del color, us recomano l'article de la Viquipèdia, que està prou bé.

${ }^{26}$ He enllaçat a l'article en anglès perquè és de bon tros el més complet, però des d'allà podeu navegar cap a articles en altres llengües: al vostre gust.
} 
teoritzar sobre llurs propietats. A més a més, com que fer dibuixos com el d'(1) de vegades és una mica pesat (tot depèn de l'editor de textos que un faci servir), per simplificar la feina les representaré tot simplement com a transcripcions fonètiques com ara [tasə].

Seguim endavant, doncs, que ara podem començar a pensar sobre el contingut de la caixa negra. Imagineu a tal efecte la situació (no gaire realista, tot sigui dit) en què el vostre interlocutor pronuncia la paraula (en català) 'aigua'. Tan aviat com això passa, el vostre MAS analitzarà el senyal acústic i en produirà la representació ['ajywə] que funcionarà com a entrada de la caixa negra. Quina serà la sortida? Recordeu que hem caracteritzat la caixa negra com el mecanisme capaç d'aparellar sons amb significats $i$, per tant, una de les tasques bàsiques que podem assumir que executarà la caixa negra és, precisament, la de produir representacions de sortida on la seqüència d'entrada apareix aparellada amb el significat que convencionalment s'associa amb aquesta seqüència. Quelcom semblant a això:

$$
\left[\begin{array}{l}
\text { So ['ajywwe] } \\
\text { SIGNIFICAT [AIGUA] }
\end{array}\right]
$$

Evidentment, com abans, podeu sofisticar (2) tant com vulgueu, l'essencial és que la sortida de la caixa negra sigui un objecte complex (una paraula) que consisteixi en una representació de la seva forma fonètica aparellada amb el seu significat (en aquest cas, el significat lèxic)-els claudàtors que envolten tots dos objectes volen transmetre la idea que tota aquesta informació es troba agrupada dins d'un únic objecte complex. Com ho fa això, la caixa negra? Per respondre aquesta pregunta, cal que pensem una mica en què comporta conèixer el significat d'una paraula. El primer que cal dir en relació amb això és que la connexió entre el so i el significat no és una relació natural, com pensava, per exemple Plató, sinó que és una relació arbitrària, 
com bé ja va observar Aristòtil. Efectivament, el mateix significat (AIGUA) ${ }^{27}$ pot transmetre's en diferents llengües a través d'agrupacions de sons ben diferents com ara ['wərə] (anglès americà; ['wว:tə] en anglès britànic), [ne'ro] (grec), [ujə] (albanès), [ur] (basc), [və'da] (rus) o ['mə:?a] (àrab). A la pràctica, això comporta que els aparellaments de sons amb significats que conformen les paraules els aprenem de memòria i que emmagatzemem cada nova paraula que aprenem en algun lloc des d'on, quan ens cal, podem recuperar-la. Els lingüistes usen el terme lexicó per referir-se a aquest repositori mental de paraules. Podeu pensar en el lexicó com si fos l'equivalent mental d'un diccionari, amb una entrada per a cada paraula on s'especifica la seva forma i el seu significat-(2) podria ser l'entrada del lexicó català per a la paraula 'aigua'. És gairebé segur que aquesta no és la manera com està organitzat el lexicó, però, atesos els objectius que vull assolir amb aquest exemple tan simple, podeu tranquil-lament imaginar-vos-el així. Per tant, i amb aquesta imatge una mica grollera del lexicó, podem tanmateix imaginar què faria la caixa negra en el moment de rebre la forma fonètica construïda pel MAS: iniciaria un procés de cerca en el lexicó usant aquesta forma fonètica com a pista $i$, tan aviat com trobés una forma coincident, generaria un exemplar de la paraula complet amb la seva forma i el seu signficat, quelcom semblant també a (2). Podem assumir, de fet, que el lexicó és un dels components de la caixa negra, que es comença a fer cada vegada més transparent a mida que avancem. Certament, si usar el llenguatge només comportés proferir paraules aillades, com és el cas en els sistemes de crits d'alarma de moltes espècies de primats, ja ho tindríem tot: la FL humana seria simplement el resultat d'acoblar un MAS amb un lexicó, més un mecanisme de cerca per tal d'executar la tasca d'identificar les paraules pronunciades pels nostres interlocutors. És prou clar, però, que això no pot ser així, ja que tot parlant és capaç de produir i comprendre expressions complexes com ara en Pol va servir l'aigua en un got, què va servir en Pol en un got?, on va servir l'aigua en Pol?, etc., el significat de les quals difícilment pot derivar-se a partir d'una simple cerca en el lexicó de les paraules que

\footnotetext{
${ }_{27}$ Com que no sabem com són els significats (de fet, ni tan sols sabem si realment són d'alguna manera), seguiré una convenció prou estesa de representar-los com a paraules ortogràfiques pero amb lletra VERSALETA.
} 
les componen. Necessàriament, i per molt important que sigui el lexicó, cal complementar-lo amb alguna altra cosa. Per fer-vos una idea de què podria ser aquesta 'altra cosa' us poposo de fer un nou experiment mental.

En aquesta ocasió, vull que imagineu un infant. Noi o noia, com vulgueu, aquesta dada no és rellevant. El que sí que és rellevant és que l’infant que imagineu no hagi anat encara a escola (és massa petit) i que visqui en un entorn monolingüe (per simplificar les coses) en el qual la llengua que es parla és l'alemany. Ja? Bé, doncs, imagineu que el nostre infant està adquirint la pròpia llengua com qualsevol altre infant i que no s'observa cap anormalitat en el seu desenvolupament, de tal manera que arriba un moment en què és capaç de dir (i comprendre) frases com les següents:

(3)a. Die Omahatmir gesagtdassder Mond scheint la.NOM àvia haPRO.1STP.SG.DAT dit que el.NOM lluna brilla 'L'àvia m'ha dit que la lluna brilla'

b. Der Opahatmir gesagtdassdie Sonne scheint

el.NOM avi ha PRO.1STP.SG.DAT dit que la.NOM sol brilla

'L'avi m'ha dit que el sol brilla'

Sí, ho reconec, són unes frases una mica ximples, però em van molt bé per posar l'èmfasi en alguns punts que m’interessa destacar. Primerament, vull cridar la vostra atenció sobre el fet que l'alemany és una llengua flexiva amb tres gèneres (masculí, femení i neutre), dos nombres (singular i plural) i quatre casos (nominatiu, acusatiu, datiu i genitiu). Aquestes categories morfològiques s'expressen en els noms, els adjectius, els articles i els pronoms. D'aquí les abreviatures en versaleta que apareixen en les glosses de (3), que ens informen, per exemple, que la paraula 'die' és un article femení singular en nominatiu; similarment, 'mir' es un pronom de primera persona del singular en datiu, etc. Noteu, per tant, que, per exemple, la paraula que vol dir LLUNA en alemany és masculina, mentre que la que vol dir SOL és femenina. Segonament, vull posar l'èmfasi sobre un punt que no és menys rellevant pel fet de ser obvi: el nostre personatge és perfectament capaç de produir qualsevol d'aquestes frases sense cometre errors en l'aplicació d'aquestes categories. ${ }^{28} \mathrm{En}$

\footnotetext{
28 Això no és del tot cert, ja que els infants durant el procés d’adquisició sí que fan allò que tècnicament s'anomen errors. El que és rellevant és que els errors dels infants no són de la mateixa mena que, per exemple, els errors
} 
altres paraules, la conducta lingüística del nostre personatge s'ajusta perfectament al que podríem considerar que són les regles gramaticals de l'alemany, es comporta com si estigués seguint aquestes regles, com si les sabés, com si sabés què són els noms i els verbs, com si sabés què són els casos i quan és apropiat usar-ne un o altre, com si sabés que el verb principal en alemany sempre ha d'anar al final, etc.

En les darreres afirmacions del paràgraf anterior he usat la cursiva com a recurs per indicar que potser no hem d'interpretar les paraules de manera literal, malgrat que, i això no us hauria de sorprendre, la majoria de lingüistes tendeix a recolzar la hipòtesi que la resposta a la pregunta 'què sap un parlant quan sap una llengua?' és, precisament, 'la gramàtica d'aquella llengua'. Val a dir que l'expressió 'la gramàtica d'aquella llengua' és com un terme paraigua que ens serveix per anomenar quelcom que no sabem exactament com és ni com està organitzat. De tota manera, no seria faltar (gaire) a la veritat afirmar que hi ha un cert consens entre els lingüistes en assumir que la FL té l'estructura mínima que teniu representada a la figura 5 i que em servirà de guia per anar desgranant les conclusions finals d'aquest article.

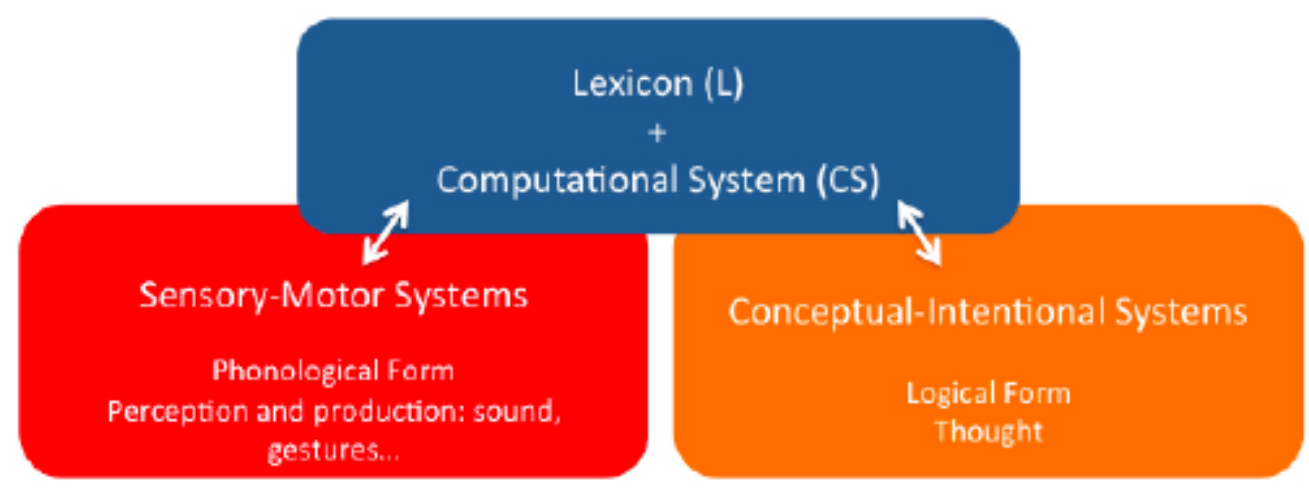

Figura 5: L’estructura mínima de la FL (o del 'fenotip lingüístic'). La seva estructura tripartita es correspon aproximadament amb l'organització que ja havíem identificat a les

que cometria un adult que està aprenent alemany. Allò que observem en el llenguatge infantil són desviaments en relació amb la parla adulta que són tanmateix predictibles i aparentment regits per algun tipus de regla, com si els infants estiguessin fent servir la seva pròpia versió de les regles gramaticals. A més a més, els errors en la parla dels infants són universals en el sentit que tots els infants els produeixen en algun moment del procés i que tots els infants produeixen el mateix tipus d'errors independentment de quina sigui la llengua que estan adquirint, com és el cas de la regularització dels verbs irregulars en formes com 'vivit' en lloc de 'viscut' en català o ‘ponido' en lloc de 'puesto' en castellà. 
figures 3 i 4. [Imatge adaptada de la Figura 1 d'aquest article que vaig publicar el 2015 en col·laboració amb Guillermo Lorenzo.]

Comencem pel rectangle vermell que porta l'etiqueta 'Sensory-Motor Systems' ('Sistemes Sensomotrius'). Això és, a grans trets, el MAS inserit dins d'una unitat funcional major. Recordeu que en comentar la figura 4 vaig identificar la funció del MAS amb la tasca de construir representacions fonètiques/fonològiques a partir de les propietats dels estímuls acústics. Aquesta és una tasca perceptiva que és bàsica en el procés de comprensió dels estímuls lingüístics i que es correspon amb la part 'sensorial' de l'etiqueta. És nogensmenys evident que com a parlants som capaços de comprendre i de produir llenguatge, de tal manera que, quan volem dir alguna cosa, cal un mecanisme que informi el nostre aparell articulatori de quins gestos ha d'executar per tal de produir els sons que conformen les paraules que volem pronunciar; amb això cobrim la part 'motora' de l'etiqueta. ${ }^{29}$

Passem ara a comentar els altres dos components. Noteu, primerament, la fletxa blanca que connecta el component vermell amb el component blau, amb l'etiqueta 'Lexicon + Computational System'. Establint un para"lelisme entre aquesta figura i les altres que hem comentat, el component blau de la figura 5 es correspon amb la 'Caixa Negra' de la figura 3. Recordeu que més amunt ja he parlat del lexicó com a un dels seus principals subcomponents; com evidencia la imatge, hi ha un altre subcomponent dins la caixa negra, el 'Sistema Computacional' (SC), del qual me n'ocupo immediatament. Abans, però, mireu-vos un moment el requadre taronja amb l'etiqueta 'Conceptual-Intentional System' ('Sistema Conceptual-Intencional'; CI).

Recordeu l'ús que feia més amunt de la paraula 'intencional' gairebé com a sinònim de 'semàntic', de manera que aquest component representa tot allò que té a

\footnotetext{
${ }^{29}$ Noteu que en el quadre vermell apareixen les paraules 'sound' and 'gestures', on la segona s'inclou per capturar el fet que les llengües de signes utilitzen un canal diferent que les llengües parlades. És a dir, les llengües parlades usen el canal oral-auditiu, mentre que les llengües signades segueixen el canal gestual-visual. La idea és, per tant, que els components més 'profunds' de la FL (els rectangles blau i taronja de la figura) no estan tallats a mesura per funcionar amb un o altre mode d'externalització, per usar una expressió prou estesa avui en dia per fer referència al sistema representat pel requadre vermell de la figura.
} 
veure amb el significat i la interpretació de les expressions lingüístiques: l'el-lipse tramada en verd de la figura 3.

Per fer-vos una idea de què fan el SC i el CI, considereu les frases de (4):

(4) a. Una jove veu l'amenaça.

b. Va veure la noia amb uns binocles.

Suposo que us heu adonat que aquestes frases són ambigües i que, en absència de la informació contextual necessària per optar per una o altra lectura, es comporten com cubs de Necker lingüístics (figura [6]), en el sentit que podem passar d'una lectura a l'altra a voluntat cada vegada que les tornem a llegir.

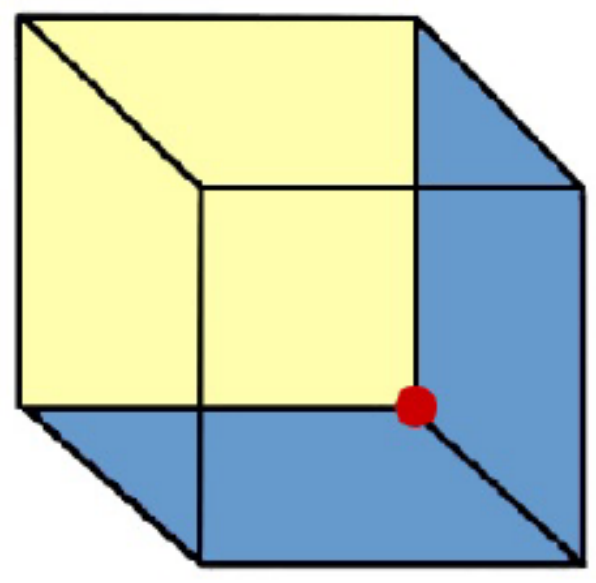

Figura 6: El cub deNecker. Onés el punt vermell? Dins ofora? [Imatge original del web Your Amazing Brain.]

Considereu, primer, (4a), que repeteixo aquí com a (5), on he usat colors per identificar les dues lectures:

(5) a. Unajoveveu l'amenaça.

b. Unajoveveul'amenaça.

En la lectura que es correspon amb (5a), tenim que una noia jove té una experiència perceptiva (pot ser visual, però no cal que sigui així) específica, concretament la presència d'algun tipus d'amenaça o perill; en la lectura 
corresponent a (5b), en canvi, tenim una veu, que pertany a una persona jove, que està amenaçant algú. És interessant mirar d'identificar la font d'aquestes ambigüitats. Suposo que us heu adonat que la clau aquí és que les paraules 'jove', 'veu' i 'amenaça' que apareixen tant a (5a) com a (5b) són homòfones i que són, de fet, paraules diferents amb significats diferents: 'jove' pot ser un nom però també pot ser un adjectiu; 'veu' pot ser una forma del verb 'veure' o un nom; 'amenaça' pot ser un nom o una forma del verb 'amenaçar'. Noteu, també, com suggereixen els colors en cada exemple, que en atribuir una o altra lectura a aquestes paraules obtenim també estructures diferents en cada cas i que, per tant, és l'estructura la que determina el significat de l'expressió. Evidentment, allò que fa que l'expressió sigui un cub de Necker lingüístic és el fet que no tenim res que ens permeti deduir quina és la interpretació volguda, ens manca informació contextual però aquesta informació, crucialment, no és informació lingüística. D’acord amb això, quan processem l'estímul acústic corresponent a l'expressió una jove veu l'amenaça el SC haurà de buscar les paraules en el lexicó, igual que feia en l'exemple en què només teníem una paraula, però ara també haurà de construir l'estructura pertinent que, en aquest cas, són dues estructures, atesa l'ambigüitat de les paraules, i que després haurà d'interpretar el CI. Probablement ja heu arribat a la conclusio que la paraula 'estructura' aquí es refereix de fet a l'estructura sintàctica i que sense estructura sintàctica no hi ha interpretació semàntica possible. En el cas de (5), el CI rebrà dues estructures sintàctiques, una per a cada lectura, i sobre la base de la informació contextual que sigui rellevant en aquell moment en triarà l'una o l'altra.

Considereu ara el cas de (4b), que és una mica diferent i que repeteixo ara, també amb colors, com a (6):

(6)a.Vaveurelanoia amb uns binocles.

\section{b.Vaveurela noiaambuns binocles.}

Aquí també tenim dues lectures, pero en aquest cas la font de l'ambigüitat no és l'homofonia d'algunes de les paraules que conté l'expressió. Fixeu-vos que, en tots dos casos, tenim algú que ha tingut una experiència visual. També en tots dos casos el nostre voyeur ha vist una noia. L'única diferència és que en un cas-(6a)-, qui 
veu ho fa amb l'ajuda d'uns binocles, és a dir que els binocles són l'instrument de veure, mentre que en l'altra lectura-(6b)-, els binocles no són un instrument, sinó simplement un objecte que la noia porta a les mans, potser, i que la distingeixen d'altres noies que hi pugui haver en l'escena. Aquesta ambigüitat és de naturalesa eminentment sintàctica, ja que la frase amb uns binocles pot modificar sigui el verb va veure que el nom la noia. Aquest exemple és important perquè mostra que necessàriament hi ha una relació d'una a una entre les estructures sintàctiques i les representacions semàntiques. En altres paraules, la semàntica d'una expressió ve totalment determinada per la seva sintaxi. Sense sintaxi, no hi ha semàntica. I, per tant, tampoc llenguatge.

\section{Conclusió}

En aquest article he intentat presentar els principis i supòsits bàsics sobre els quals es recolza la lingüística. Com hem vist, aquests principis i supòsits no són gaire diferents dels que adopten altres ciències com la biologia, la física o les ciències naturals en general. En tant que ciència, per tant, la lingüística estudia i intenta comprendre com funciona una part concreta del món en què vivim, allò que hem anomenat Llenguatge, primer, i Facultat del Llenguatge (o FL), després. La FL no és quelcom d'abstracte o intangible l'estructura de la qual anem descobrint pura i simplement a través de l'aplicació de la nostra facultat de raonar, com fan els matemàtics quan defineixen l'estructura d'un espai vectorial en $\mathbb{R}^{3}$ o determinen quina és la funció derivada d'un polinomi. No, la FL és un objecte material i tangible que podem estudiar empíricament, fent experiments (mentals o de laboratori) i construint teories. Que la FL no sigui directament observable no es contradiu amb el que acabo de dir, ja que no podem mesurar el grau de realitat de les coses a partir d'allò que està a l'abast dels nostres sentits: les partícules elementals de què està feta la matèria, els gens, la majoria de les molècules, els púlsars, els forats negres, els camps magnètics, els camps gravitatoris, no són entitats visibles a ull nu, però la seva activitat o presència és detectable $i$ analitzable per mitjans indirectes, sovint observant els efectes causats per aquesta activitat. En aquest article hem après a dissenyar alguns experiments (de fet, n'hem fet més d'un, d'experiment) que ens han 
permès de detectar l'activitat de la FL per tal d'estudiar-ne l'estructura i el funcionament. No hem fet res que no faria també un físic, un químic o un biòleg i, seguint els mateixos principis metodològics que seguiria qualsevol d'aquests científics, hem arribat a conclusions prou interessants sobre la FL. Per exemple, hem descobert que darrere la paraula 'sintaxi' s'amaga una capacitat que tots els humans tenim, la d'assignar una estructura a una entitat que comença la seva existència essent només una ona sonora; i hem après també que sense aquesta estructura no hi ha interpretació semàntica possible. Hem après, en definitiva, que els humans som un virtuosos de la sintaxi. Pensar sobre la FL ens ha permès de descobrir quelcom nou sobre nosaltres mateixos, els humans, perquè pensar sobre la FL és, de fet, una manera, de vegades la més directa, d’interrogar-se sobre la naturalesa humana.

\section{Bibliografia}

Balari, Sergio \& Lorenzo, Guillermo. 2010. Communication: "Where evolutionary linguistics went wrong”. Biological Theory 5(3): 228-239.

Balari, Sergio \& Lorenzo, Guillermo. 2015. It is an organ, it is new, but it is not a new organ. Conceptualizing language from a homological perspective. Frontiers in Ecology and Evolution 3:58. doi: 10.3389/fevo.2015.00058.

Chomsky, Noam. 1975. Reflections on Language. Nova York: Pantheon Books.

Chomsky, Noam. 1993. Language and Thought. Wakefield, RI: Moyer Bell.

Darwin, Charles. 1859. The Origin of Species. Londres: John Murray.

Descartes, René. 1648. "Comments on a certain broadsheet". In J. Cottingham, R. Stoothof \& D. Murdoch, eds. The Philosophical Writings of Descartes. Vol. I, pp. 293-312. Cambridge: Cambridge University Press, 1985.

Descartes, René. 1664. "The World or Treatise on Light". In J. Cottingham, R. Stoothof \& D. Murdoch, eds. The Philosophical Writings of Descartes. Vol. I, pp. 81-98. Cambridge: Cambridge University Press, 1985.

Joos, Martin. 1958. "Comments on Phonemic overlapping by Bernard Bloch". In Martin Joos, ed., Readings in Linguistics. The Development of Descriptive Linguistics in America since 1925, p. 96. Nova York: American Council of Learned Societies.

Saussure, Ferdinand de. 1916. Cours de linguistique générale. Ed. Charles Bally \& Albert Sechehaye, París: Payot. 
Scholz, Barbara C., Pelletier, Francis Jeffry and Pullum, Geoffrey K. 2016. Philosophy of Linguistics, The Stanford Encyclopedia of Philosophy (Winter 2016 Edition), Edward N. Zalta (ed.), URL = $<$ https://plato.stanford.edu/archives/win2016/entries/linguistics/>.

von Baer, Karl Ernst. 1876. Ueber Darwin's Lehre. In Reden gehalten in wissenschaftlichen Versammlungen und kleinere Aufsätze vermischten Inhalts. Zweiter Teil, pp. 261-506. Sant Petersburg: Karl Röttger. 